\title{
Properties of a 50/50 Mixture of Jet-A + S-8
}

Thomas J. Bruno Arno Laesecke Stephanie L. Outcalt Hans-Dieter Seelig Beverly L. Smith 



\section{Properties of a 50/50 Mixture of Jet-A + S-8}

Thomas J. Bruno

Arno Laesecke

Stephanie L. Outcalt Hans-Dieter Seelig Beverly L. Smith

Thermophysical Properties Division

325 Broadway

Boulder, CO 80305

March 2007

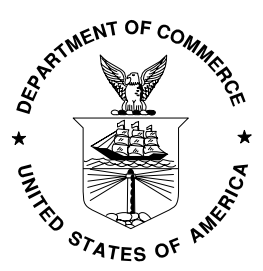

U.S. Department of Commerce Carlos M. Gutierrez, Secretary

Technology Administration Robert Cresanti, Under Secretary for Technology 


\section{Executive Summary}

- Report of the chemical analyses of Jet-A and S-8 (samples received from AFRL).

- Report of the distillation curves of 50/50, 25/75 and 75/25 Jet-A + S-8.

- Report of density survey measurements of 50/50 Jet-A + S-8.

- Report of viscosity survey measurements of 50/50 Jet-A + S-8.

- Report of speed of sound survey measurements of 50/50 Jet-A + S-8.

- Report of compressed liquid density measurements of 50/50 Jet-A + S-8. 


\section{Contents}

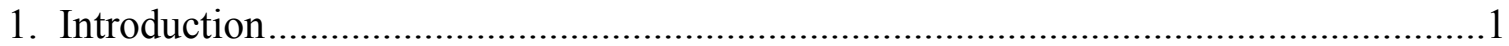

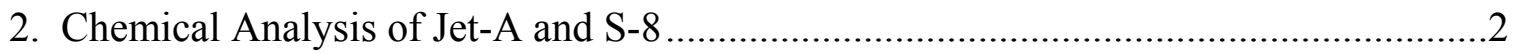

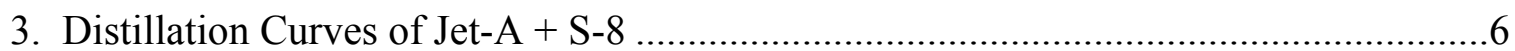

4. Density (at Atmospheric Pressure) for 50/50 Jet-A + S-8 .....................................14

5. Viscosity (at Atmospheric Pressure) for 50/50 Jet-A + S-8 ...................................19

6. Speed of Sound Measurement (at Atmospheric Pressure) for 50/50 Jet-A $+\mathrm{S}-8$.......23

7. Correlations for the Density, Viscosity, and Speed of Sound of 50/50 Jet-A + S-8 ....27

8. Compressed Liquid Density Measurements for 50/50 Jet-A + S-8 ..........................28

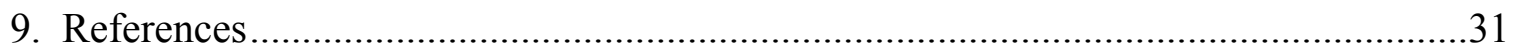





\title{
Properties of a 50/50 Mixture of Jet-A + S-8*
}

\author{
Thomas J. Bruno, Arno Laesecke, Stephanie L. Outcalt \\ Hans-Dieter Seelig, and Beverly L. Smith \\ National Institute of Standards and Technology \\ 325 Broadway \\ Boulder, Colorado 80305
}

\begin{abstract}
This report describes measurement efforts performed on mixture(s) of aviation fuels: Jet-A $+\mathrm{S}-8$. The primary mixture is a $50 / 50$ ( $\mathrm{vol} / \mathrm{vol}$ ) combination of the two fuels. Measurements include chemical analysis, density, viscosity, speed of sound and vapor pressure (by a distillation curve measurement). This document compiles in one source the available measured data for the mixture.
\end{abstract}

Keywords: density; distillation curve; speed of sound; thermal conductivity; vapor pressure; viscosity

\section{Introduction}

The major gas turbine fuel that is currently the most common fuel used by the United States military is JP-8 (MIL-DTL-83133), a kerosene fraction that has a higher flash point than the main military predecessor, JP-4 [1]. JP-8 was first introduced at NATO bases in 1978, hence it was also called NATO F-34, and is currently the U.S. Air Force's primary fuel, and the primary fuel for U.S. Navy shore-based aviation. Aboard aircraft carriers, the major fuel is JP-5, which has an even higher flash point (desirable for safety considerations), although its higher cost restricts its use to the specialized fire control needs of aircraft carriers. JP-8 is very similar to Jet A-1, the most common commercial gas turbine fuel, with the major differences being in the additive package. JP-8 contains an icing inhibitor, corrosion/lubricity enhancer and anti-static additive. Jet-A (U.S. domestic commercial jet fuel) differs from Jet-A1 (non-U.S. commercial jet fuel) primarily in freezing point $\left(-40{ }^{\circ} \mathrm{C}\right.$ as opposed to $-47{ }^{\circ} \mathrm{C}$, respectively). The understanding of the properties of JP-8 must necessarily begin with understanding the properties of Jet-A, since the fluids are very similar and because the additive package is often varied to suit applications, climatic regions, and supply streams.

Environmental concerns, and the potential of disruptions in supply, have led to the development of new aviation fuels based on the Fischer Tropsch process. One such fuel made from natural gas is designated as S-8 (the "S" referring to synthetic; CAS No. 437986-20-4) [2]. This fluid, which is intended as a synthetic JP-8, is a hydrocarbon mixture rich in $\mathrm{C} 7$ to $\mathrm{C} 18$ linear and branched

\footnotetext{
* Note: In order to describe materials and experimental procedures adequately, it is occasionally necessary to identify commercial products by manufacturers' names or labels. In no instance does such identification imply endorsement by the National Institute of Standards and Technology, nor does it imply that the particular product or equipment is necessarily the best available for the purpose.
} 
akanes. It has a flash point range between $37.8^{\circ} \mathrm{C}$ and $51.8^{\circ} \mathrm{C}$, an auto ignition temperature of $210^{\circ} \mathrm{C}$, and explosive limits in air between 0.7 and 5 (vol/vol). It is clear in appearance (no dye is added to current formulations) and somewhat lower in density, viscosity, and speed of sound transmission than typical formulations of Jet-A and JP-8. It is likely that initial applications of S8 will be in formulations mixed with either JP-8 or Jet-A. In view of the comments above on the differences between Jet-A and JP-8, the AFRL desired measured properties of a 50/50 (vol/vol) mixture of Jet-A and S-8 to guide formulations of test fuel mixtures. This document summarizes the measurements done at NIST on this mixture.

The samples of Jet-A and S-8 were obtained from AFRL. The sample of Jet-A was designated POSF-4658, and was a composite sample that was prepared by AFRL from several samples from several manufacturers. The S-8 was designated POSF-4734. The 50/50 (vol/vol) mixtures were prepared volumetrically at ambient temperature (approximately $23{ }^{\circ} \mathrm{C}$ ) and atmospheric pressure (approximately $83.2 \mathrm{kPa}$ ) by use of mixing cylinders. The uncertainty in the volume during the preparation of mixtures was $0.1 \mathrm{~mL}$. For the remainder of this report, we will commonly refer to the resulting mixture as Jet-A + S-8, or simply as "the mixture."

\section{Chemical Analyses of Jet-A and S-8}

A sample of Jet-A, designated as POSF-4658, was presented for analysis. This sample is a composite made from a number of individual lots of Jet-A. The sample was drawn with a disposable pipette from a half-gallon steel pail supplied by AFRL. The sample had a very pale yellow cast, and did not appear to have any dying agent. The sample appeared to have a viscosity and odor typical of kerosenes.

The sample was analyzed with a gas chromatography-mass spectrometry method. A $30 \mathrm{~m}$ capillary column with a $0.1 \mu \mathrm{m}$ coating of $5 \%$ phenyl polydimethyl siloxane was chosen as the stationary phase [3]. This phase provides separations based upon boiling temperature and also the polarity of the solute. In this context, polarity also includes points of unsaturation or aromaticity on the solute molecule. Sample was injected via syringe into a split/splitless injector set with a 100 to 1 split ratio. The injector was operated at a temperature of $350{ }^{\circ} \mathrm{C}$ and a constant head pressure of 8 psig. The sample residence time in the injector was very short; thus the effect of sample exposure to this high temperature is expected to be minimal. The column was temperature programmed to provide complete and rapid elution with minimal loss of peak shape. Initially, the temperature was maintained isothermally at $60^{\circ} \mathrm{C}$ for $2 \mathrm{~min}$, followed by a $2{ }^{\circ} \mathrm{C} / \mathrm{min}$ ramp to $90{ }^{\circ} \mathrm{C}$, followed by a $10{ }^{\circ} \mathrm{C} / \mathrm{min}$ ramp to $250{ }^{\circ} \mathrm{C}$. Although the analysis was allowed to run for $40 \mathrm{~min}$, all peaks were eluted after approximately $27 \mathrm{~min}$. Mass spectra were collected for each peak from 15 to $550 \mathrm{RMM}$ units [4]. Integration of the areas under each peak was done with a commercial algorithm optimized to identify peaks that were at least an order of magnitude larger than the noise level.

Before any analysis was done, the mass spectrometer was tuned with a sample of perfluorotributyl amine [3]. Then, after the tune settings were optimized, a blank run was done to ensure the absence of extraneous or ghost components, and to determine stationary phase background. 
Table 1. The analysis of Jet-A by gas chromatography-mass spectrometry.

\begin{tabular}{|c|c|c|c|c|c|c|c|}
\hline $\begin{array}{c}\text { Peak } \\
\text { no. }\end{array}$ & $\begin{array}{l}\text { Retention } \\
\text { time, min }\end{array}$ & $\begin{array}{c}\text { Peak } \\
\text { profile }\end{array}$ & $\begin{array}{c}\text { Correlation } \\
\text { coefficient }\end{array}$ & $\begin{array}{l}\text { Confi- } \\
\text { dence }\end{array}$ & Name & CAS No. & $\begin{array}{c}\text { Area } \\
\text { percentage }\end{array}$ \\
\hline $\mathrm{A}$ & 1.726 & $\mathrm{~S}$ & 72.9 & $\mathrm{H}$ & n-heptane & $142-82-5$ & 0.125 \\
\hline $\mathrm{B}$ & 1.878 & $\mathrm{~S}$ & 76.9 & $\mathrm{H}$ & methyl cyclohexane & $108-87-2$ & 0.198 \\
\hline $\mathrm{C}$ & 2.084 & $\mathrm{~S}$ & 71.6 & $\mathrm{H}$ & 2-methyl heptane & $592-27-8$ & 0.202 \\
\hline 1 & 2.144 & $\mathrm{~S}$ & 29.2 & $\mathrm{H}$ & toluene & $108-88-3$ & 0.320 \\
\hline $\mathrm{D}$ & 2.223 & $\mathrm{~S}$ & 41.9 & $\mathrm{H}$ & cis-1,3-dimethyl cyclohexane & $638-04-0$ & 0.161 \\
\hline 2 & 2.351 & $\mathrm{~S}$ & 44.0 & $\mathrm{H}$ & n-octane & $111-65-9$ & 0.386 \\
\hline $\mathrm{E}$ & 2.945 & $\mathrm{~S}$ & 31.1 & $\mathrm{H}$ & 1,2,4-trimethyl cyclohexane & $2234-75-5$ & 0.189 \\
\hline 3 & 3.036 & $\mathrm{~S}$ & 12.4 & $\mathrm{H}$ & 4-methyl octane & $2216-34-4$ & 0.318 \\
\hline 4 & 3.169 & $\mathrm{~S}$ & 37.6 & $\mathrm{H}$ & 1,2-dimethyl benzene & $95-47-6$ & 0.575 \\
\hline 5 & 3.527 & $\mathrm{~S}$ & 33.9 & $\mathrm{H}$ & n-nonane & $111-84-2$ & 1.030 \\
\hline 6 & 3.921 & $\mathrm{~S}$ & NA & $\mathrm{U}$ & $?$ & & 0.321 \\
\hline 7 & 4.066 & S \& A & NA & $\mathrm{H}$ & $\mathrm{X}$-methyl nonane & NA & 0.597 \\
\hline 8 & 4.576 & S \& A & 7.97 & $\mathrm{M}^{\mathrm{a}}$ & 4-methyl nonane & 17301-94-9 & 0.754 \\
\hline 9 & 4.655 & $\mathrm{~S}$ & 35.8 & $\mathrm{H}$ & 1-ethyl-3-methyl benzene & $620-14-4$ & 1.296 \\
\hline 10 & 4.764 & $\mathrm{~S}$ & 10.7 & $\mathrm{H}$ & 2,6-dimethyl octane & $2051-30-1$ & 0.749 \\
\hline 11 & 4.836 & A & 5.27 & $\mathrm{U}^{\mathrm{b}}$ & $\begin{array}{l}\text { 1-methyl-3-(2-methylpropyl) } \\
\text { cyclopentane }\end{array}$ & 29053-04-1 & 0.285 \\
\hline 12 & 5.012 & $\mathrm{~S}$ & 27.8 & $\mathrm{M}^{\mathrm{b}}$ & 1-ethyl-4-methyl benzene & $622-96-8$ & 0.359 \\
\hline 13 & 5.049 & $\mathrm{~A}$ & 13.7 & $\mathrm{M}^{\mathrm{b}}$ & 1-methyl-2-propyl cyclohexane & $4291-79-6$ & 0.370 \\
\hline 14 & 5.291 & $\mathrm{~S}$ & 26.3 & $\mathrm{H}$ & 1,2,4-trimethyl benzene & $95-63-6$ & 1.115 \\
\hline 15 & 5.325 & $\mathrm{~S}$ & 37.7 & $\mathrm{H}$ & n-decane & $124-18-5$ & 1.67 \\
\hline 16 & 5.637 & $\mathrm{~S}$ & 36 & $\mathrm{H}$ & 1-methyl-2-propyl benzene & $1074-17-5$ & 0.367 \\
\hline 17 & 5.825 & $\mathrm{~S}$ & 36 & $\mathrm{H}$ & 4-methyl decane & $2847-72-5$ & 0.657 \\
\hline 18 & 5.910 & $\mathrm{~S}$ & 26.9 & $\mathrm{H}$ & 1,3,5-trimethyl benzene & $108-67-8$ & 0.949 \\
\hline 19 & 6.073 & S \& A & NA & $\mathrm{M}$ & X-methyl decane & NA & 0.613 \\
\hline 20 & 6.176 & $\mathrm{~S}$ & 5.01 & $\mathrm{M}^{\mathrm{b}}$ & 2,3-dimethyl decane & $17312-44-6$ & 0.681 \\
\hline 21 & 6.364 & $\mathrm{~S} \& \mathrm{~A}$ & 25.7 & $\mathrm{M}^{\mathrm{b}}$ & $\begin{array}{l}\text { 1-ethyl-2,2,6-trimethyl } \\
\text { cyclohexane }\end{array}$ & $71186-27-1$ & 0.364 \\
\hline 22 & 6.516 & S \& A & 35.6 & $\mathrm{H}$ & 1-methyl-3-propyl benzene & $1074-43-7$ & 0.569 \\
\hline $\mathrm{F}$ & 6.662 & S \& A & NA & $\mathrm{U}^{\mathrm{b}}$ & aromatic & NA & 0.625 \\
\hline 23 & 6.589 & $\mathrm{~S}$ & 20.4 & $\mathrm{M}^{\mathrm{c}}$ & 5-methyl decane & $13151-35-4$ & 0.795 \\
\hline 24 & 6.728 & $\mathrm{~S}$ & 22.9 & $\mathrm{H}$ & 2-methyl decane & $6975-98-0$ & 0.686 \\
\hline 25 & 6.862 & $\mathrm{~A}$ & 23.2 & $\mathrm{H}$ & 3-methyl decane & $13151-34-3$ & 0.969 \\
\hline 26 & 7.110 & $\mathrm{~S}$ & NA & $\mathrm{U}$ & Aromatic & NA & 0.540 \\
\hline 27 & 7.159 & $\mathrm{~S}$ & NA & $\mathrm{U}$ & Aromatic & NA & 0.599 \\
\hline 28 & 7.310 & $\mathrm{~S}$ & 17.9 & $\mathrm{M}$ & 1-methyl-(4-methylethyl) benzene & $99-87-6$ & 0.650 \\
\hline 29 & 7.626 & $\mathrm{~A}$ & 22.0 & $\mathrm{H}$ & n-undecane & $1120-21-4$ & 2.560 \\
\hline 29 & 7.971 & $\mathrm{~A}$ & NA & $\mathrm{M}$ & $\mathrm{x}$-methyl undecane & NA & 1.086 \\
\hline 30 & 8.875 & $\mathrm{~A}$ & 22.3 & $\mathrm{M}$ & 1-ethyl-2,3-dimethyl benzene & $933-98-2$ & 1.694 \\
\hline 31 & 9.948 & $\mathrm{~A}$ & 19.6 & $\mathrm{H}$ & n-dodecane & $112-40-3$ & 3.336 \\
\hline 32 & 10.324 & $\mathrm{~S}$ & 19.0 & $\mathrm{H}$ & 2,6-dimethyl undecane & $17301-23-4$ & 1.257 \\
\hline 33 & 12.377 & $\mathrm{~S} \& \mathrm{~A}$ & 10.8 & $\mathrm{H}$ & n-tridecane & $629-50-5$ & 3.998 \\
\hline $33 a$ & 12.901 & $\mathrm{~S}$ & 24.1 & $\mathrm{M}$ & $\begin{array}{l}\text { 1,2,3,4-tetrahydro-2,7-dimethyl } \\
\text { naphthalene }\end{array}$ & $13065-07-1$ & 0.850 \\
\hline $33 \mathrm{~b}$ & 13.707 & $\mathrm{~S}$ & 3.5 & $\mathrm{M}$ & 2,3-dimethyl dodecane & $6117-98-2$ & 0.657 \\
\hline $33 \mathrm{c}$ & 14.138 & $\mathrm{~S}$ & 14.5 & $\mathrm{M}$ & 2,6,10-trimethyl dodecane & $3891-98-3$ & 0.821 \\
\hline $33 d$ & 13.834 & $\mathrm{~S}$ & NA & $\mathrm{M}$ & x-methyl tridecane & NA & 0.919 \\
\hline $33 \mathrm{e}$ & 13.998 & $\mathrm{~S}$ & NA & $\mathrm{M}$ & $\mathrm{x}$-methyl tridecane & NA & 0.756 \\
\hline 34 & 14.663 & $\mathrm{~S}$ & 29.8 & $\mathrm{H}$ & n-tetradecane & $629-59-4$ & 1.905 \\
\hline 35 & 16.86 & $\mathrm{~S}$ & 24.7 & $\mathrm{H}$ & n-pentadecane & $629-62-9$ & 1.345 \\
\hline
\end{tabular}

a Trailing impurity

b Highly impure composite peak

c There is evidence of an aromatic impurity in this peak, coeluting 
The results of the analysis are provided in Table 1 . The numbered peaks are the largest peak areas recorded on the total ion chromatogram (1\% or higher). Note that these areas are raw areas and have not been calibrated with a standard. Lettered peaks are for components between 0.7 and $1 \%$, provided the chromatography is good. Double lettered peaks are very early eluting components that were included to provide a suite of light components for potential future model development. These peaks were chosen in part for their elution order and chromatographic purity.

A sample of S-8, designated POSF 4734, was presented for analysis. The sample was drawn with a disposable pipette from a half-gallon steel pail supplied by the AFRL. Approximately $0.5 \mathrm{~mL}$ of the fluid was drawn and stored in a tightly capped scintillation vial until used. The liquid sample was clear, and appeared to have a viscosity lower than that of a typical kerosene. The liquid had little discernable odor. The same method used for Jet-A was applied for the analysis of S-8. The results of this analysis are provided in Table 2.

A number of clear differences may be seen in the chemical analyses. First, the sample of Jet-A has a typical kerosene composition in that a number of aromatic constituents can be observed. No aromatic constituents are listed in Table 2 for S-8. Indeed, no aromatics were detected in S-8 in any of the analyses that were performed. A second striking feature is the large number of linear or simple branched alkanes that are present in S-8, in contrast to the more complex constituents found in Jet-A. This is not surprising considering that the feed stock of S-8 is a paraffinic wax derived by the Fischer-Tropsch process from natural gas. This paraffinic wax is cracked and extensively isomerized to obtain the S-8 jet fuel.

The samples of Jet-A and S-8 were further examined for hydrocarbon types by use of a mass spectrometric classification method summarized in ASTM Method D-2789 [5]. In this method, one uses mass spectrometry (or gas chromatography-mass spectrometry) to characterize hydrocarbon samples into six types. The six types or families are paraffins, monocycloparaffins, dicycloparaffins, alkylbenzenes (or aromatics), indanes and tetralins (grouped as one classification), and naphthalenes. Although the method is specified only for application to low olefinic gasolines, it is of practical relevance to many complex fluid analyses, and is often applied to gas turbine fuels, rocket propellants, and missile fuels. The uncertainty of this method, and the potential pitfalls, are discussed elsewhere. For the hydrocarbon type analysis of the distillate fraction samples, $1 \mu \mathrm{L}$ samples were injected into the GC-MS. Because of this consistent injection volume, no corrections were needed for sample volume. The results of these analyses are provided in Table 3 . 
Table 2. Detailed analysis for S-8, POSF 4734, provided by AFRL. The peak lettering and numbering scheme are described in the text.

\begin{tabular}{|c|c|c|c|c|c|c|c|}
\hline $\begin{array}{c}\text { Peak } \\
\text { no. }\end{array}$ & $\begin{array}{l}\text { Retention } \\
\text { time, min }\end{array}$ & $\begin{array}{c}\text { Peak } \\
\text { profile }\end{array}$ & $\begin{array}{c}\text { Correlation } \\
\text { coefficient }\end{array}$ & $\begin{array}{l}\text { Confi- } \\
\text { dence }\end{array}$ & Name & CAS No. & $\begin{array}{c}\text { Area } \\
\text { percentage }\end{array}$ \\
\hline aa & 2.119 & $\mathrm{~S}$ & 72.2 & $\mathrm{H}$ & 2-methyl heptane & $592-27-8$ & 0.32 \\
\hline $\mathrm{bb}$ & 2.162 & $\mathrm{~A}$ & 41.4 & $\mathrm{H}$ & 3-methyl heptane & $589-81-1$ & 0.43 \\
\hline $\mathrm{a}$ & 2.310 & $\mathrm{~A}$ & 26.3 & $\mathrm{H}$ & 1,2,3-trimethyl cyclopentane & 15890-40-1 & 0.96 \\
\hline 1 & 2.564 & $\mathrm{~A}$ & 44.2 & $\mathrm{H}$ & 2,5-dimethyl heptane & $2216-30-0$ & 1.13 \\
\hline 2 & 2.803 & A & 33.9 & $\mathrm{H}$ & 4-methyl octane & $2216-34-4$ & 2.506 \\
\hline 3 & 2.869 & $\mathrm{~A}$ & 16.9 & $\mathrm{H}$ & 3-methyl octane & $2216-33-3$ & 1.323 \\
\hline 4 & 3.123 & A & 21.6 & $\mathrm{H}$ & n-nonane & $111-84-2$ & 1.623 \\
\hline 5 & 3.358 & $\mathrm{~A}$ & 18.5 & $\mathrm{M}$ & 3,5-dimethyl octane & $15869-96-9$ & 1.035 \\
\hline $\mathrm{b}$ & 3.456 & $\mathrm{~A}$ & 29.0 & $\mathrm{H}$ & 2,6-dimethyl octane & 2051-30-1 & 0.756 \\
\hline 6 & 3.682 & $\mathrm{~A}$ & 54.4 & $\mathrm{H}$ & 4-ethyl octane & $15869-86-0$ & 1.032 \\
\hline 7 & 3.757 & $\mathrm{~A}$ & 39.8 & $\mathrm{H}$ & 4-methyl nonane & $17301-94-9$ & 1.904 \\
\hline 8 & 3.792 & $\mathrm{~S}$ & 39.2 & $\mathrm{H}$ & 2-methyl nonane & $871-83-0$ & 1.019 \\
\hline 9 & 3.866 & $\mathrm{~A}$ & 26.9 & $\mathrm{H}$ & 3-methyl nonane & 5911-04-6 & 1.385 \\
\hline 10 & 4.186 & $\mathrm{~A}$ & 51.4 & $\mathrm{H}$ & n-decane & $124-18-5$ & 2.050 \\
\hline 11 & 4.390 & $\mathrm{~A}$ & 16.7 & $\mathrm{M}$ & 2-5-dimethyl nonane & $17302-27-1$ & 1.175 \\
\hline 12 & 4.750 & $\mathrm{~S}$ & 12.0 & $\mathrm{M}$ & 5-ethyl-2-methyl octane & $62016-18-6$ & 1.015 \\
\hline 13 & 4.820 & $\mathrm{~A}$ & 37.7 & $\mathrm{H}$ & 5-methyl decane & $13151-35-4$ & 1.315 \\
\hline 14 & 4.859 & A & 42.1 & $\mathrm{H}$ & 4-methyl decane & $2847-72-5$ & 1.134 \\
\hline 15 & 4.902 & $\mathrm{~A}$ & 35.4 & $\mathrm{H}$ & 2-methyl decane & $6975-98-0$ & 1.529 \\
\hline 16 & 4.980 & $\mathrm{~A}$ & 44.1 & $\mathrm{H}$ & 3-methyl decane & 13151-34-3 & 1.583 \\
\hline 17 & 5.312 & $\mathrm{~A}$ & 50.1 & $\mathrm{H}$ & n-undecane & $1120-21-4$ & 2.420 \\
\hline $\mathrm{c}$ & 5.484 & $\mathrm{~A}$ & NA & $\mathrm{M}$ & x-methyl undecane & NA & 1.590 \\
\hline 18 & 5.664 & A & 11.9 & $\mathrm{M}$ & 3-methyl undecane & $1002-43-3$ & 1.15 \\
\hline 19 & 5.906 & $\mathrm{~A}$ & 37.3 & $\mathrm{H}$ & 5-methyl undecane & $1632-70-8$ & 1.696 \\
\hline 20 & 5.949 & $\mathrm{~A}$ & 29.5 & $\mathrm{H}$ & 4-methyl undecane & $2980-69-0$ & 1.045 \\
\hline 21 & 5.996 & $\mathrm{~A}$ & 15.1 & $\mathrm{M}$ & 2-methyl undecane & $7045-71-8$ & 1.072 \\
\hline 22 & 6.074 & $\mathrm{~A}$ & 7.9 & $\mathrm{U}$ & 2,3-dimethyl undecane & $17312-77-5$ & 1.213 \\
\hline 23 & 6.387 & $\mathrm{~A}$ & 43.9 & $\mathrm{H}$ & n-dodecane & $112-40-3$ & 2.595 \\
\hline $\mathrm{d}$ & 6.606 & A & 8.3 & $\mathrm{M}$ & 4-methyl dodecane & $6117-97-1$ & 0.929 \\
\hline $\mathrm{e}$ & 6.668 & $\mathrm{~A}$ & NA & $\mathrm{H}$ & x-methyl dodecane & NA & 0.744 \\
\hline 24 & 7.024 & $\mathrm{~S}$ & 28.7 & $\mathrm{H}$ & 2-methyl dodecane & $1560-97-0$ & 1.293 \\
\hline 25 & 7.094 & $\mathrm{~S}$ & NA & $\mathrm{M}$ & x-methyl dodecane & NA & 1.281 \\
\hline 28 & 7.383 & $\mathrm{~A}$ & 36.0 & $\mathrm{H}$ & n-tridecane & $629-50-5$ & 1.739 \\
\hline $\mathrm{f}$ & 7.923 & $\mathrm{~A}$ & 8.7 & $\mathrm{U}$ & 4-methyl tridecane & $26730-12-1$ & 0.836 \\
\hline 29 & 7.970 & $\mathrm{~A}$ & 9.8 & $\mathrm{U}$ & 6-propyl tridecane & $55045-10-8$ & 1.052 \\
\hline 30 & 8.040 & $\mathrm{~A}$ & NA & $\mathrm{M}$ & x-methyl tridecane & NA & 1.066 \\
\hline 31 & 8.306 & $\mathrm{~A}$ & 23.3 & $\mathrm{H}$ & n-tetradecane & $629-59-4$ & 1.562 \\
\hline 32 & 8.396 & $\mathrm{~A}$ & NA & $\mathrm{M}$ & x-methyl tetradecane & NA & 1.198 \\
\hline $\mathrm{g}$ & 8.490 & $\mathrm{~S}$ & 6.4 & M & 5-methyl tetradecane & $25117-32-2$ & 0.720 \\
\hline 33 & 8.728 & $\mathrm{~S}$ & 10.2 & $\mathrm{H}$ & n-pentadecane & $629-62-9$ & 1.032 \\
\hline $\mathrm{H}$ & 9.232 & $\mathrm{~A}$ & NA & $\mathrm{M}$ & x-methyl tetradecane & NA & 0.727 \\
\hline
\end{tabular}


Table 3. A summary of the hydrocarbon type analysis as provided by ASTM D-2789, for Jet-A4658 and S-8-4734.

\begin{tabular}{ccccccc}
\hline Fluid & Paraffins & $\begin{array}{c}\text { Monocyclo- } \\
\text { paraffins }\end{array}$ & $\begin{array}{c}\text { Dicyclo- } \\
\text { paraffins }\end{array}$ & $\begin{array}{c}\text { Alkyl- } \\
\text { aromatics }\end{array}$ & $\begin{array}{c}\text { Indanes } \\
\text { and } \\
\text { tetralins } \\
\text { Vol \% }\end{array}$ & $\begin{array}{c}\text { Naphth- } \\
\text { alenes }\end{array}$ \\
\hline $\begin{array}{c}\text { Jet-A- } \\
4658\end{array}$ & 46.5 & 22.5 & 5.4 & 18.4 & 4.5 & 2.4 \\
\hline $\begin{array}{c}\text { S-8- } \\
4734\end{array}$ & 80.0 & 17.3 & 0.9 & 0.1 & 0 & 1.9 \\
\hline
\end{tabular}

Especially striking is the paraffin content, which for S-8 is $80 \%$ as compared with $46.5 \%$ for Jet-A. Also striking is the difference in the aromatic fraction (which is consistent with the observation made earlier from the detailed analyses presented in Tables 1 and 2). The alkylaromatic content result for Jet-A was $18.4 \%$, while for S-8 it is negligible. In addition, S- 8 has no discernable indanes or tetralins by ASTM-D-2789.

\section{Distillation Curves of Jet-A + S-8}

One of the most important methods of characterizing complex fluids is the measurement of the distillation curve. Simply stated, the distillation curve is a plot of the distillation temperature of the fluid plotted against the volume fraction distilled [6]. We have recently introduced an advanced approach to the measurement of the distillation curve that takes the information content to a much higher level [7-14]. The new metrology provides:

- $\quad$ actual onset of boiling temperatures (the vapor rising temperature),

- a composition explicit data channel for each distillate fraction (for both qualitative and quantitative analysis),

- $\quad$ temperature measurements that are true thermodynamic state points, termed $\mathrm{T}_{\mathrm{k}}$

- the energy content of each distillate fraction,

- $\quad$ consistency with a century of historical data, presented as $T_{h}$

- $\quad$ explicit identification of azeotropes in fractions,

- $\quad$ trace chemical analysis of each distillate fraction, and

- corrosivity assessment of each distillate fraction.

Distillation curves were measured for several mixtures of Jet-A + S-8 (25/75, 50/50 and 75/25, Jet-A $+\mathrm{S}-8$, vol/vol). The mixture concentrations listed are nominal values mainly for identification purposes, however the uncertainty in preparation of the mixtures with mixing cylinders was $0.1 \mathrm{~mL}$. The onset of boiling behavior of the mixtures is presented first in Table 4 . In this table, the temperatures have been corrected to what would be obtained at 1 atmosphere, with the modified Sidney Young equation [6, 15-17]:

$$
\mathrm{C}_{\mathrm{c}}=\mathrm{C}\left(760-\mathrm{P}_{\mathrm{a}}\right)\left(273+\mathrm{T}_{\mathrm{c}}\right),
$$


Table 4. The onset of boiling behavior for three mixtures of Jet-A + S-8.

\begin{tabular}{|c|c|c|c|c|c|}
\hline $\begin{array}{l}\text { Observed } \\
\text { temperature, } \\
{ }^{\circ} \mathrm{C}\end{array}$ & S-8 & $\begin{array}{l}\text { 75/25 S-8 } \\
+ \text { Jet-A }\end{array}$ & $\begin{array}{l}\text { 50/50 S-8 } \\
+ \text { Jet-A }\end{array}$ & $\begin{array}{l}\text { 25/75 S-8 + } \\
\text { Jet-A }\end{array}$ & Jet-A 4658 \\
\hline Onset & 163.0 & 160.9 & 154.9 & 161.8 & 139.9 \\
\hline Sustained & 168.6 & 182.3 & 178.6 & 178.9 & 185.6 \\
\hline Vapor rising & 181.9 & 184.8 & 186.6 & 189.1 & 190.5 \\
\hline
\end{tabular}

where $\mathrm{C}_{\mathrm{c}}$ is the correction added to the observed temperature, $\mathrm{C}$ is a constant, $0.00012, \mathrm{~Pa}$ is the atmospheric pressure in millimeters of mercury, and $T_{c}$ is the measured temperature in centigrade. In fact, the original Sidney Young equation specifies that $\mathrm{C}_{\mathrm{c}}$ is dependent upon the average hydrocarbon chain length of the fluid, ranging from 0.000135 for a single carbon to 0.000119 for 8 carbons. A linear correlation of these factors can be used to predict a value for simple fluids. In this work, $\mathrm{C}$ was set to 0.000109 [15-17], a value that corresponds to a carbon chain of 12. The actual experimental pressures were $83.5 \mathrm{kPa}, 82.4 \mathrm{kPa}$, and $83.7 \mathrm{kPa}$ for the $75 / 25,50 / 50$, and 25/75 mixtures, respectively. From these data and the corrected temperatures, one can recover the raw measured temperatures with the Sidney Young equation.

Representative distillation curve data for the three mixtures of Jet-A with S-8, along with data for the starting materials, are presented in Table 5 . In this table we provide both $T_{k}$ and $T_{h}$ (where $T_{k}$ is measured directly in the fluid while $T_{h}$ is measured in the distillation head). The $T_{k}$ value is a true thermodynamic state point that can be modeled theoretically, while the $\mathrm{T}_{\mathrm{h}}$ data allow comparison with earlier measurements made with typical distillation curve instrumentation. In this table, the estimated uncertainty in the temperatures (with a coverage factor $\mathrm{k}=2$ ) is $0.1{ }^{\circ} \mathrm{C}$. Note that the experimental uncertainty of $T_{k}$ is actually somewhat lower than that of $T_{h}$, but as a conservative position, we use the higher value for both temperatures. The uncertainty in the volume measurement that is used to obtain the distillate volume fraction is $0.05 \mathrm{~mL}$ in each case.

The distillation curves based on the data from Table 5 are presented in Figure 1. The shapes of all of the curves are of the subtle sigmoid type that one would expect for a highly complex fluid with many components, distributed over a large range of relative molecular mass. There is no indication of the presence of azeotropic constituents, since there is an absence of multiple inflections and curve flattening.

The relationship between $T_{k}$ and $T_{h}$ is presented in Figure 2, in which both temperatures are presented for the mixture data shown in Table 2 . We note that $T_{k}$ always leads $T_{h}$. This behavior is consistent with a complex mixture with a continually changing composition. Note that when these two temperatures converge, it is evidence of either a single component being generated (by vaporization) in the kettle, or the presence of an azeotrope that controls the composition of both phases. The absence of such a convergence in Figure 2 can be interpreted as further evidence of the absence of azeotropic behavior. This is in contrast to what was observed for the gasoline oxygenates, in which the convergence of $T_{k}$ and $T_{h}$ (due to azeotrope formation) was observed [12]. 
Tk vs. Th of $75 / 25$ S-8/Jet-A
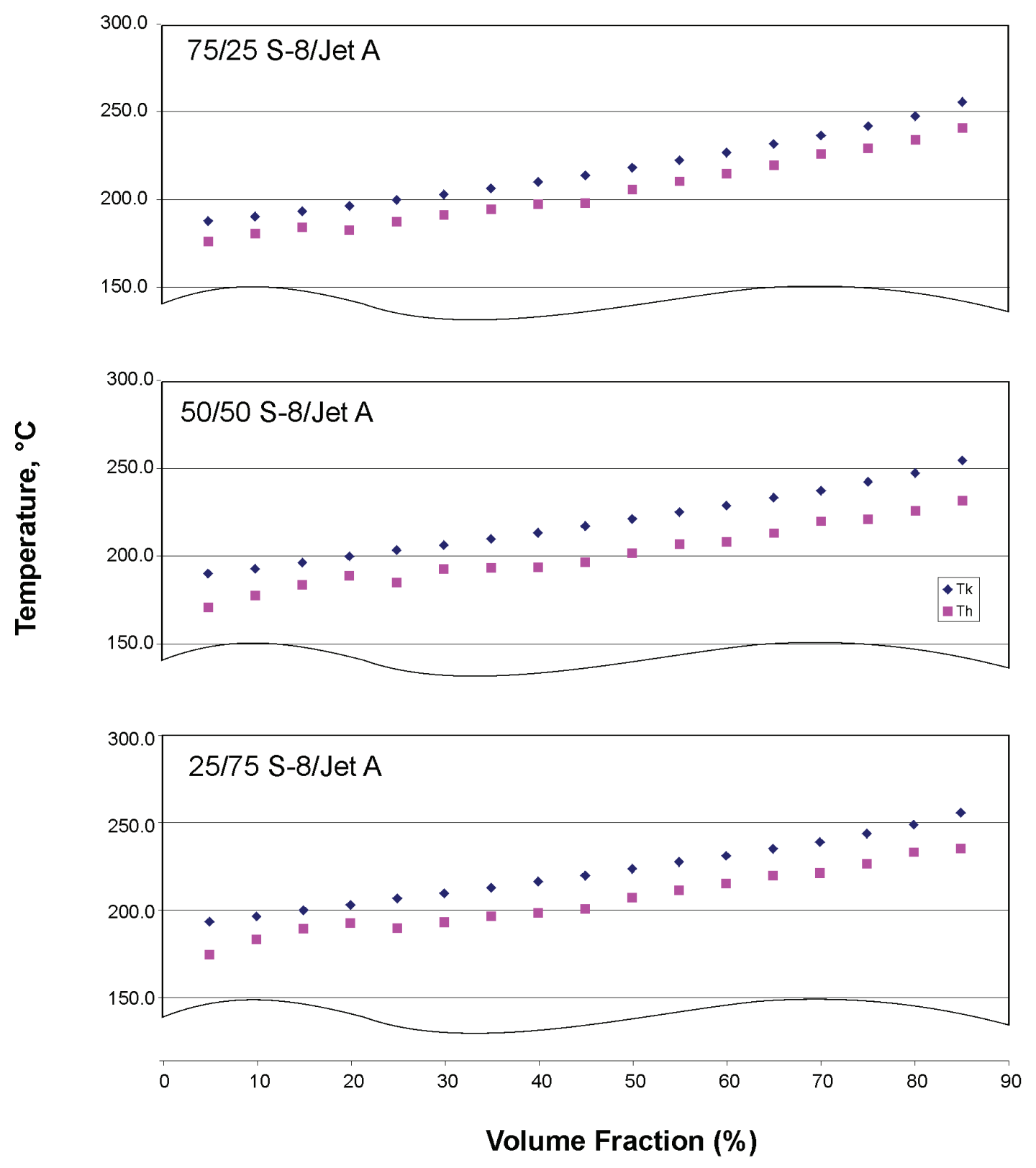

Figure 2. The relationship of $T_{k}$ and $T_{h}$ for the three mixtures of S- $8+$ Jet-A-4658 measured in this work. 
While the gross examination of the distillation curves is instructive and valuable for many design purposes, the composition channel of the advanced approach can provide even greater understanding and information content. One can sample and examine the individual fractions as they emerge from the condenser, as discussed in the introduction. Following the analytical procedure described, samples were collected and prepared for analysis. Chemical analyses of each fraction were done by gas chromatography with flame ionization detection and mass spectrometric detection. Representative chromatograms (measured by flame ionization detection) for each fraction of Jet-A-4658 are shown in Figure 3. The time axis is from 0 to 12 min for each chromatogram, and the abundance axis is presented in arbitrary units of area counts (voltage slices). It is clear that although there are many peaks on each chromatogram (30 to 40 major peaks, and 60 to 80 minor and trace peaks), these chromatograms are much simpler than those of the neat fluids, which can contain 300 to 400 peaks. At the very start of each chromatogram is the solvent front, which does not interfere with the sample. One can follow the progression of the chromatograms in Figure 3 as the distillate fraction becomes richer in the heavier components. This figure illustrates just one chemical analysis strategy that can be applied to the distillate fractions. It is possible to use any analytical technique that is applicable to solvent-borne liquid samples that might be applicable to a given application.

The distillate fractions of the three Jet-A + S-8 mixtures, along with the starting Jet-A and S-8 fluids, were examined for hydrocarbon types by use of a mass spectrometric classification method summarized in ASTM Method D-2789 [5]. The results of these hydrocarbon type analyses are presented in Tables 6a to 6d, and plotted in Figure 4. The first line in each of the tables reports the results of the analysis as applied to the entire sample (called the composite) rather than to distillate fractions. The data listed in this line are actually averages of two separate determinations; one done with a neat sample of the fuel (that is, with no added solvent) and the other with the sample in n-hexane. The volume of the neat sample was $0.2 \mu \mathrm{L}$, and only these mass spectra were corrected for sample volume. All of the distillate fractions presented in the table were measured in the same way as the composite (m/z range from 15 to $550 \mathrm{RMM}$ units gathered in scanning mode, each spectrum corrected by subtracting trace air and water peaks).

In general, the hydrocarbon type fractions for the composite (the first row in each table) are consistent with the compositions obtained for the distillate fractions (the remaining rows of each table). Thus, taking the S-8 fluid as an example, the paraffin fraction for the composite sample was found to be $80.0 \%$, while the fractions ranged from 79.1 to 87.8 . We have noted, however, that with the composite samples (which naturally produce a much more complex total ion chromatogram), one obtains many more non-integral $\mathrm{m} / \mathrm{z}$ peaks on the mass spectrum. Thus, for a distillate fraction, one might obtain a peak at $\mathrm{m} / \mathrm{z}=43.0$, while for the composite one might obtain $\mathrm{m} / \mathrm{z}=43.0,43.15$, etc., despite the resolution of the instrument being only 1 unit of mass. Our practice has been to round the fractional masses to the nearest integral mass, a practice that can sometimes cause bias. This is an unavoidable vagary of the instrument that can potentially be remedied with a higher resolution mass spectrometer. We maintain that the comparability among the distillate fractions is not affected by this characteristic, although the intercomparability between the distillate fractions and the composite should be approached with a bit more caution. 

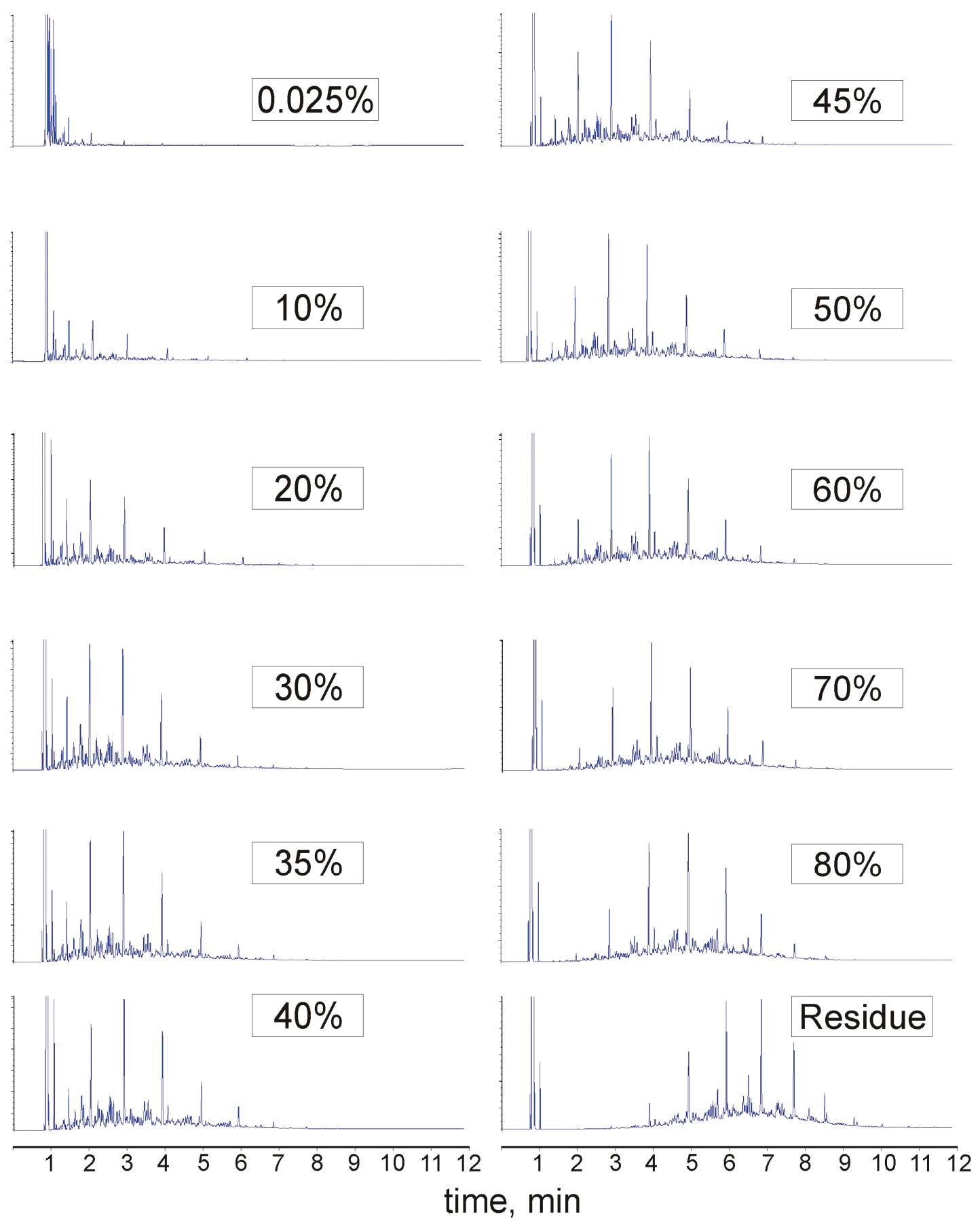

Figure 3. Chromatograms of distillate fractions of Jet-A-4658, presented in arbitrary units of intensity (from a flame ionization detector) plotted against time. 
Table 6. Summary of the results of hydrocarbon family calculations based on the method of ASTM D-2789.

Table 6a. 75/25 S-8/Jet-A.

\begin{tabular}{|c|c|c|c|c|c|c|}
\hline $\begin{array}{c}\text { Distillate } \\
\text { volume } \\
\text { fraction, } \\
\%\end{array}$ & Paraffins & $\begin{array}{c}\text { Monocyclo- } \\
\text { paraffins } \\
\text { Vol \% }\end{array}$ & $\begin{array}{l}\text { Dicyclo- } \\
\text { paraffins } \\
\text { Vol \% }\end{array}$ & $\begin{array}{c}\text { Alkyl- } \\
\text { aromatics } \\
\text { Vol \% }\end{array}$ & $\begin{array}{l}\text { Indanes } \\
\text { and } \\
\text { tetralins } \\
\text { Vol \% }\end{array}$ & $\begin{array}{c}\begin{array}{c}\text { Naphth- } \\
\text { alenes }\end{array} \\
\text { Vol \% }\end{array}$ \\
\hline Composite & 75.3 & 22.0 & 0.4 & 1.2 & 0.2 & 0.9 \\
\hline 0.025 & 74.1 & 22.2 & 0.2 & 3.2 & 0.0 & 0.3 \\
\hline 10 & 77.9 & 19.1 & 0.1 & 2.6 & 0.0 & 0.3 \\
\hline 20 & 76.7 & 19.9 & 0.1 & 2.9 & 0.0 & 0.4 \\
\hline 30 & 76.6 & 20.0 & 0.1 & 2.9 & 0.0 & 0.5 \\
\hline 35 & 77.6 & 19.2 & 0.1 & 2.7 & 0.0 & 0.4 \\
\hline 40 & 75.9 & 20.1 & 0.3 & 3.0 & 0.2 & 0.6 \\
\hline 45 & 81.5 & 16.3 & 0.0 & 1.9 & 0.0 & 0.2 \\
\hline 50 & 78.1 & 18.9 & 0.2 & 2.3 & 0.1 & 0.5 \\
\hline 60 & 78.9 & 18.4 & 0.1 & 1.7 & 0.1 & 0.7 \\
\hline 70 & 72.3 & 21.6 & 1.4 & 2.3 & 0.8 & 1.6 \\
\hline 80 & 84.1 & 15.2 & 0.0 & 0.1 & 0.0 & 0.6 \\
\hline Residue & 83.1 & 16.5 & 0.0 & 0.0 & 0.0 & 0.4 \\
\hline
\end{tabular}

Table 6b. 50/50 S-8/Jet-A.

\begin{tabular}{|c|c|c|c|c|c|c|}
\hline $\begin{array}{c}\text { Distillate } \\
\text { volume } \\
\text { fraction, } \\
\%\end{array}$ & Paraffins & $\begin{array}{c}\text { Monocyclo- } \\
\text { paraffins }\end{array}$ & $\begin{array}{c}\text { Dicyclo- } \\
\text { paraffins }\end{array}$ & $\begin{array}{c}\text { Alkyl- } \\
\text { aromatics }\end{array}$ & $\begin{array}{c}\text { Indanes } \\
\text { and } \\
\text { tetralins } \\
\text { Vol \% }\end{array}$ & $\begin{array}{c}\text { Naphth- } \\
\text { alenes }\end{array}$ \\
\hline Composite & 65.4 & 23.5 & 6.1 & 8.8 & 3.0 & 2.3 \\
\hline 0.025 & 66.7 & 22.9 & 0.4 & 9.6 & 0.0 & 0.3 \\
\hline 10 & 67.9 & 23.3 & 0.5 & 7.8 & 0.2 & 0.4 \\
\hline 20 & 68.9 & 22.3 & 0.5 & 7.7 & 0.2 & 0.4 \\
\hline 30 & 70.6 & 20.9 & 0.3 & 7.4 & 0.3 & 0.5 \\
\hline 35 & 70.8 & 20.9 & 0.4 & 7.1 & 0.3 & 0.4 \\
\hline 40 & 71.3 & 20.5 & 0.4 & 6.8 & 0.4 & 0.6 \\
\hline 45 & 73.2 & 19.3 & 0.3 & 6.4 & 0.3 & 0.5 \\
\hline 50 & 71.9 & 20.0 & 0.4 & 6.2 & 0.8 & 0.8 \\
\hline 60 & 70.4 & 21.7 & 0.6 & 5.2 & 1.1 & 1.0 \\
\hline 70 & 73.1 & 20.9 & 0.4 & 3.4 & 1.0 & 1.2 \\
\hline 80 & 76.9 & 19.4 & 0.1 & 1.5 & 0.9 & 1.2 \\
\hline Residue & 72.3 & 25.9 & 0.3 & 0.2 & 0.1 & 1.2 \\
\hline
\end{tabular}


Table 6c. 25/75 S-8/Jet-A.

\begin{tabular}{|c|c|c|c|c|c|c|}
\hline $\begin{array}{c}\text { Distillate } \\
\text { volume } \\
\text { fraction, } \\
\%\end{array}$ & Paraffins & $\begin{array}{c}\text { Monocyclo- } \\
\text { paraffins }\end{array}$ & $\begin{array}{c}\text { Dicyclo- } \\
\text { paraffins }\end{array}$ & $\begin{array}{c}\text { Alkyl- } \\
\text { aromatics }\end{array}$ & $\begin{array}{c}\text { Indanes } \\
\text { and } \\
\text { tetralins } \\
\text { Vol \% }\end{array}$ & $\begin{array}{c}\text { Naphth- } \\
\text { alenes }\end{array}$ \\
\hline Vol \% \\
\hline Composite & 48.1 & 25.6 & 8.5 & 11.3 & 4.2 & 2.5 \\
\hline 0.025 & 56.2 & 26.5 & 1.3 & 15.3 & 0.4 & 0.3 \\
\hline 10 & 56.7 & 25.1 & 1.5 & 15.5 & 0.7 & 0.5 \\
\hline 20 & 60.9 & 22.3 & 0.7 & 15.2 & 0.5 & 0.5 \\
\hline 30 & 56.7 & 24.6 & 1.8 & 14.5 & 1.6 & 0.8 \\
\hline 35 & 58.1 & 23.9 & 1.5 & 14.1 & 1.6 & 0.8 \\
\hline 40 & 57.0 & 24.9 & 1.9 & 13.3 & 1.9 & 1.0 \\
\hline 45 & 59.9 & 23.6 & 1.2 & 12.4 & 1.8 & 1.1 \\
\hline 50 & 60.7 & 23.4 & 1.3 & 11.5 & 1.9 & 1.2 \\
\hline 60 & 65.5 & 21.5 & 0.6 & 8.9 & 2.1 & 1.4 \\
\hline 70 & 62.4 & 24.9 & 1.3 & 6.9 & 2.6 & 1.9 \\
\hline 80 & 59.9 & 27.1 & 2.7 & 4.9 & 3.0 & 2.4 \\
\hline
\end{tabular}

Table 6d. Jet-A 4658.

\begin{tabular}{|c|c|c|c|c|c|c|}
\hline $\begin{array}{c}\text { Distillate } \\
\text { volume } \\
\text { fraction, } \\
\%\end{array}$ & Paraffins & $\begin{array}{c}\text { Monocyclo- } \\
\text { paraffins }\end{array}$ & $\begin{array}{c}\text { Dicyclo- } \\
\text { paraffins }\end{array}$ & $\begin{array}{c}\text { Alkyl- } \\
\text { aromatics }\end{array}$ & $\begin{array}{c}\text { Indanes } \\
\text { and } \\
\text { tetralins } \\
\text { Vol \% }\end{array}$ & $\begin{array}{c}\text { Naphth- } \\
\text { alenes }\end{array}$ \\
\hline Vol \% \\
\hline Composite & 46.5 & 22.5 & 5.4 & 18.4 & 4.5 & 2.4 \\
\hline 0.025 & 40.4 & 27.3 & 3.4 & 27.3 & 1.2 & 0.5 \\
\hline 10 & 39.8 & 25.1 & 4.5 & 27.2 & 2.6 & 0.8 \\
\hline 20 & 41.2 & 24.6 & 4.4 & 25.6 & 3.1 & 1.1 \\
\hline 30 & 40.9 & 25.2 & 5.8 & 22.1 & 4.3 & 1.6 \\
\hline 35 & 43.2 & 24.5 & 4.3 & 21.9 & 4.2 & 1.8 \\
\hline 40 & 43.3 & 25.3 & 4.8 & 20.0 & 4.6 & 2.0 \\
\hline 45 & 41.7 & 25.9 & 6.4 & 18.7 & 5.0 & 2.3 \\
\hline 50 & 42.9 & 25.8 & 5.6 & 18.1 & 5.1 & 2.4 \\
\hline 60 & 43.1 & 26.4 & 6.7 & 15.0 & 5.9 & 2.9 \\
\hline 70 & 43.8 & 27.1 & 7.4 & 11.8 & 6.3 & 3.6 \\
\hline 80 & 48.7 & 29.9 & 7.0 & 6.3 & 4.6 & 3.3 \\
\hline Residue & 49.7 & 31.9 & 7.0 & 3.4 & 3.4 & 4.5 \\
\hline
\end{tabular}


Table 6e. S-8.

\begin{tabular}{|c|c|c|c|c|c|c|}
\hline $\begin{array}{c}\text { Distillate } \\
\text { volume } \\
\text { fraction, } \\
\%\end{array}$ & Paraffins & $\begin{array}{c}\text { Monocyclo- } \\
\text { paraffins }\end{array}$ & $\begin{array}{c}\text { Dicyclo- } \\
\text { paraffins }\end{array}$ & $\begin{array}{c}\text { Alkyl- } \\
\text { aromatics }\end{array}$ & $\begin{array}{c}\text { Indanes } \\
\text { and } \\
\text { tetralins } \\
\text { Vol \% }\end{array}$ & $\begin{array}{c}\text { Naphth- } \\
\text { alenes }\end{array}$ \\
\hline Composite & 80.0 & 17.3 & 0.9 & 0.1 & 0 & 1.9 \\
\hline 0.025 & 79.1 & 18.4 & 0.1 & 1.8 & 0.0 & 0.6 \\
\hline 10 & 81.2 & 16.4 & 0.0 & 1.9 & 0.0 & 0.5 \\
\hline 20 & 81.0 & 18.0 & 0.1 & 0.0 & 0.0 & 0.9 \\
\hline 30 & 80.8 & 17.9 & 0.3 & 0.0 & 0.0 & 1.1 \\
\hline 35 & 82.0 & 16.8 & 0.1 & 0.0 & 0.0 & 1.1 \\
\hline 40 & 85.8 & 13.7 & 0.0 & 0.0 & 0.0 & 0.5 \\
\hline 45 & 87.8 & 11.9 & 0.0 & 0.0 & 0.0 & 0.3 \\
\hline 50 & 85.3 & 13.8 & 0.0 & 0.0 & 0.0 & 0.9 \\
\hline 60 & 85.1 & 13.9 & 0.0 & 0.0 & 0.0 & 1.1 \\
\hline 70 & 85.1 & 13.7 & 0.0 & 0.0 & 0.0 & 1.2 \\
\hline 80 & 83.6 & 15.0 & 0.0 & 0.0 & 0.0 & 1.4 \\
\hline Residue & 84.8 & 14.7 & 0.0 & 0.0 & 0.0 & 0.5 \\
\hline
\end{tabular}

The distribution of hydrocarbon type as a function of distillate fraction is instructive among the different turbine fuel mixtures. Mixtures that have a high concentration of S-8 are seen to have a very high paraffin content, as expected. This approximate concentration ranges from $75+\%$ for the mixture that contains $75 \% \mathrm{~S}-8$, to $55+\%$ for the mixture that only contains $25 \% \mathrm{~S}-8$. For each mixture, the alkylaromatic content decreases markedly as a function of distillate fraction, and this is especially notable for the mixtures that are rich in Jet-A. For the 75/25 S-8/Jet-A mixture, the alkylaromatic concentration shows a great deal of scatter which results from its very low concentration in mixtures rich in S-8. The concentrations of the indanes and tetralins, and the naphthalenics compounds increase with distillate fraction, and this increase is especially pronounced in the mixtures that are rich in Jet-A.

\section{Density (at Atmospheric Pressure) for 50/50 Jet-A + S-8}

A Stabinger viscodensimeter (Anton Paar SVM 3000, see Figure 5 below) was used to determine the density in the temperature range from $-40{ }^{\circ} \mathrm{C}$ to $100{ }^{\circ} \mathrm{C}(233.15 \mathrm{~K}$ to $373.15 \mathrm{~K})$ at atmospheric pressure ( $83 \mathrm{kPa}$ at $1654.7 \mathrm{~m}$ altitude at Boulder, Colorado). A similar technique was used for measurements on JP-10 and S-8 $[18,19]$. The digital density analyzer in the viscodensimeter used a U-shaped vibrating sample tube and a system for electronic excitation and frequency counting. The density of the sample liquid in the vibrating tube was obtained from the resonant frequency of the vibrating system relative to the resonant frequency with a calibration liquid of known density. 
75/25 S-8/Jet-A 4658

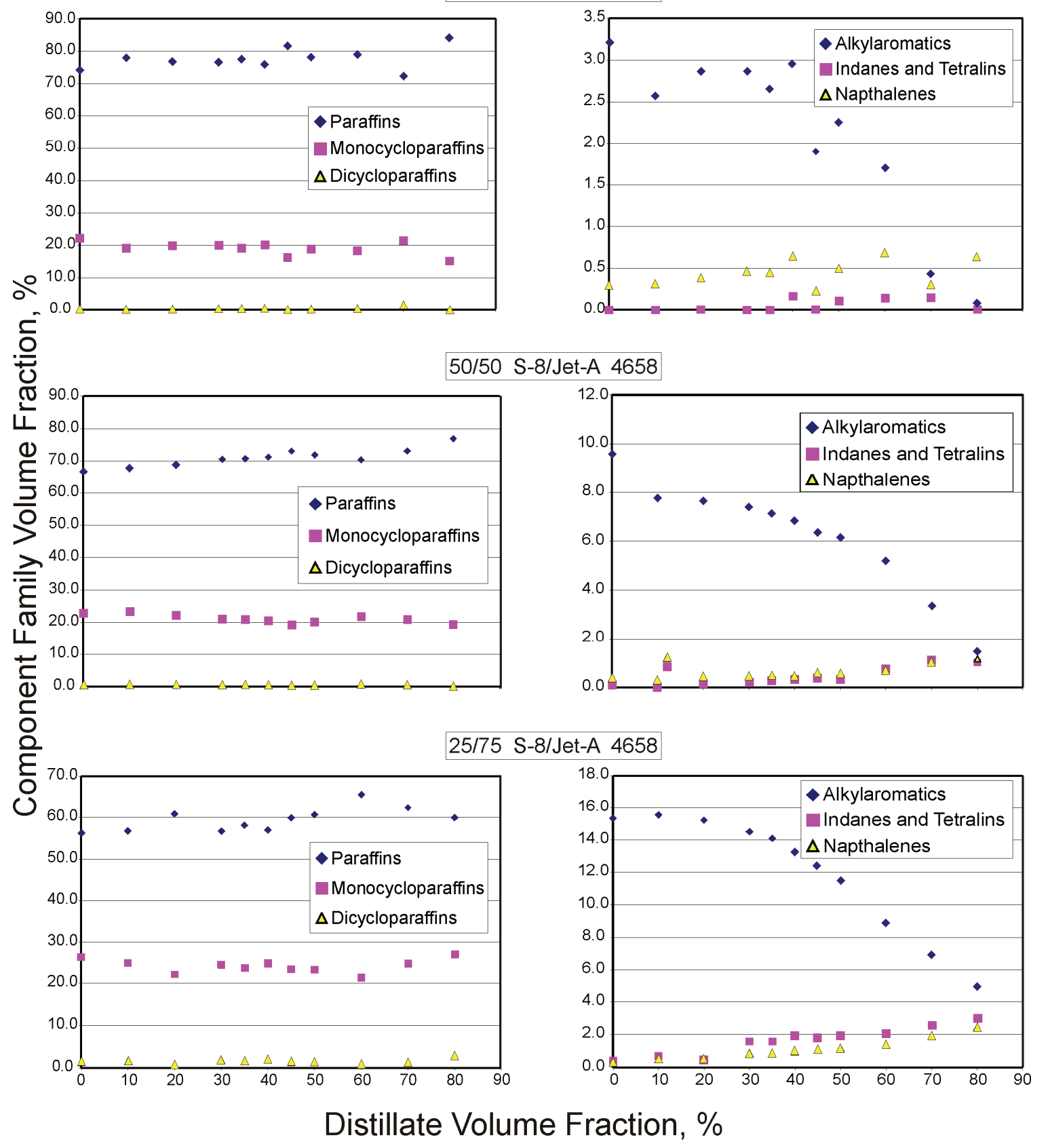

Figure 4. A plot of the hydrocarbon types resulting from the ASTM D-2789 analysis for three mixtures of Jet-A-4658 and S-8. 
The combination of a viscometer and a densimeter makes it possible to obtain absolute viscosity $\eta$ as well as kinematic viscosity, $v$ (which will be presented later in this report) of a sample because $v=\eta / \rho$ where $\rho$ is the density. The amount of sample needed for both measuring cells was less than $5 \mathrm{~mL}$. The assembly is thermostatted by a copper block that surrounds both the viscosity and the density measuring cells and kept both cells at the same temperature. A thermoelectric heating and cooling system ensured the temperature stability of the copper block within $0.005{ }^{\circ} \mathrm{C}$ from the set temperature at the position of the viscosity cell over the whole temperature range. At temperatures below $0{ }^{\circ} \mathrm{C}$ the viscodensimeter was cooled with an additional external circulator. The uncertainty $(k=2 ; 95 \%$ confidence level) of the temperature calibration was no more than $0.03{ }^{\circ} \mathrm{C}$ over the range from 15 to $100{ }^{\circ} \mathrm{C}$. Outside this range the calibration uncertainty is no more than $0.05^{\circ} \mathrm{C}$. The density measurements performed with this instrument on the $50 / 50(\mathrm{vol} / \mathrm{vol}) \mathrm{Jet}-\mathrm{A}+\mathrm{S}-8$ mixture are provided in Table 7.

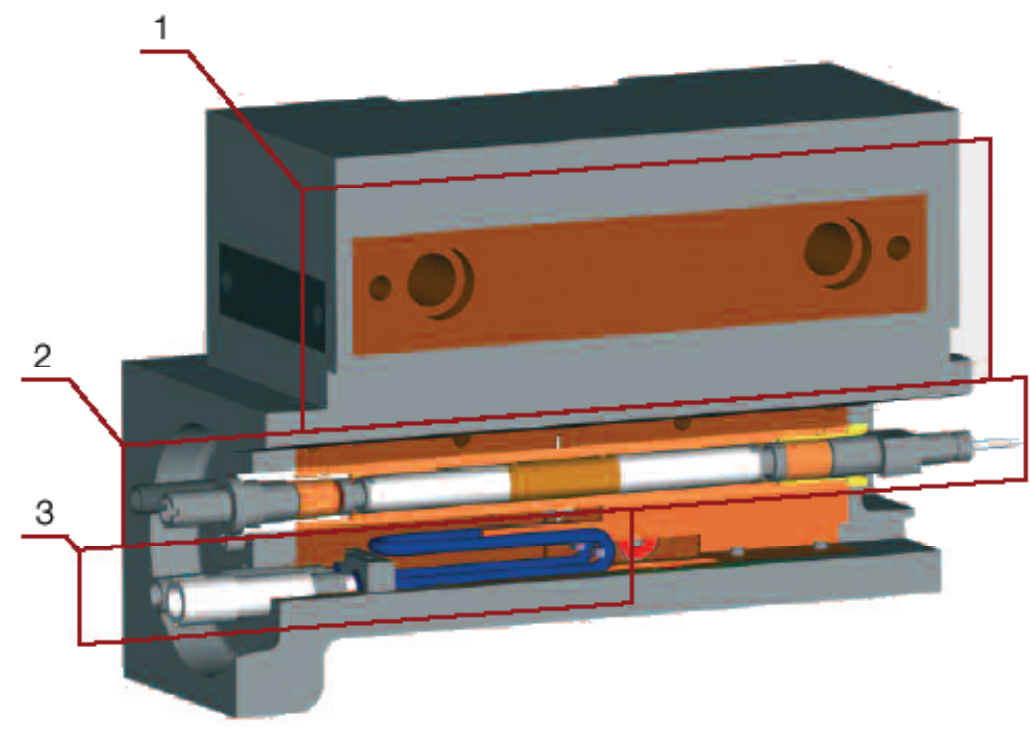

Figure 5. Main components of the Stabinger viscodensimeter SVM 3000. (1) Thermostatting Peltier block, (2) Concentric cylinder viscometer, (3) Vibrating tube densimeter. 
Table 7. Densities of 50/50 ( vol $/ \mathrm{vol})$ Jet-A $+\mathrm{S}-8$ mixture measured with the Stabinger viscodensimeter SVM 3000. The ambient pressure during the measurements was $83 \mathrm{kPa}$.

\begin{tabular}{|c|c|c|c|c|c|}
\hline $\begin{array}{c}\text { Temperature } \\
T \\
\end{array}$ & $\begin{array}{c}\text { Density } \\
\rho \\
\end{array}$ & $\begin{array}{c}\text { Temperature } \\
T \\
\end{array}$ & $\begin{array}{c}\text { Density } \\
\rho \\
\end{array}$ & \begin{tabular}{|c|} 
Temperature \\
$T$ \\
\end{tabular} & $\begin{array}{c}\text { Density } \\
\rho \\
\end{array}$ \\
\hline $\mathrm{K}$ & $\mathrm{kg} \cdot \mathrm{m}^{-3}$ & $\mathrm{~K}$ & $\mathrm{~kg} \cdot \mathrm{m}^{-3}$ & $\mathrm{~K}$ & $\mathrm{~kg} \cdot \mathrm{m}^{-3}$ \\
\hline \multicolumn{2}{|c|}{$\begin{array}{c}\text { Sample } 1 \\
\text { Run } 1\end{array}$} & \multicolumn{2}{|c|}{$\begin{array}{c}\text { Sample } 2 \\
\text { Run } 1\end{array}$} & \multicolumn{2}{|c|}{$\begin{array}{c}\text { Sample } 3 \\
\text { Run } 1\end{array}$} \\
\hline 373.15 & 719.5 & 373.16 & 719.6 & 373.15 & 719.9 \\
\hline 363.15 & 727.1 & 363.15 & 727.2 & 363.15 & 727.2 \\
\hline 353.15 & 734.6 & 353.15 & 734.6 & 353.15 & 734.8 \\
\hline 343.15 & 742.1 & 343.15 & 742.2 & 343.15 & 742.2 \\
\hline 333.15 & 749.5 & 333.15 & 749.5 & 333.15 & 749.5 \\
\hline 331.15 & 750.9 & 331.15 & 750.8 & 331.15 & 750.9 \\
\hline 329.15 & 752.3 & 329.15 & 752.3 & 329.15 & 752.3 \\
\hline 327.15 & 753.8 & 327.15 & 753.8 & 327.15 & 754.0 \\
\hline 325.15 & 755.3 & 325.15 & 755.3 & 325.15 & 755.5 \\
\hline 323.15 & 756.8 & 323.15 & 756.8 & 323.15 & 756.8 \\
\hline 321.15 & 758.3 & 321.15 & 758.2 & 321.15 & 758.3 \\
\hline 319.15 & 759.8 & 319.15 & 759.7 & 319.15 & 759.8 \\
\hline 317.15 & 761.3 & 317.15 & 761.2 & 317.15 & 761.3 \\
\hline 315.15 & 762.7 & 315.15 & 762.6 & 315.15 & 762.7 \\
\hline 313.15 & 764.2 & 313.15 & 764.0 & 313.15 & 764.2 \\
\hline 303.15 & 771.2 & 303.15 & 771.3 & 303.15 & 771.3 \\
\hline 293.15 & 778.5 & 293.15 & 778.6 & 293.15 & 778.5 \\
\hline 283.15 & 785.8 & 283.15 & 785.9 & 283.15 & 785.8 \\
\hline 273.15 & 793.0 & 273.15 & 793.1 & 273.15 & 793.1 \\
\hline 271.15 & 794.5 & 271.15 & 794.5 & 271.15 & 794.6 \\
\hline 269.15 & 795.9 & 269.15 & 795.9 & 269.15 & 796.0 \\
\hline 267.15 & 797.4 & 267.15 & 797.4 & 267.15 & 797.4 \\
\hline 265.15 & 798.8 & 265.15 & 798.9 & 265.15 & 798.9 \\
\hline 263.15 & 800.2 & 263.15 & 800.3 & 263.15 & 800.3 \\
\hline 261.15 & 801.7 & 261.15 & 801.7 & 261.15 & 801.7 \\
\hline 259.15 & 803.1 & 259.15 & 803.1 & 259.15 & 803.1 \\
\hline 257.15 & 804.5 & 257.15 & 804.6 & 257.15 & 804.6 \\
\hline 255.15 & 805.9 & 255.15 & 806.0 & 255.15 & 806.0 \\
\hline 253.15 & 807.3 & 253.15 & 807.4 & 253.15 & 807.4 \\
\hline 251.15 & 808.8 & 251.15 & 808.7 & 251.15 & 808.8 \\
\hline 249.15 & 810.2 & 249.15 & 810.2 & 249.15 & 810.2 \\
\hline 247.15 & 811.6 & 247.15 & 811.6 & 247.15 & 811.6 \\
\hline 245.15 & 813.0 & 245.15 & 813.0 & 245.15 & 813.0 \\
\hline 243.15 & 814.4 & 243.15 & 814.5 & 243.15 & 814.4 \\
\hline 241.15 & 815.8 & 241.15 & 815.8 & 241.15 & 815.8 \\
\hline 239.15 & 817.3 & 239.15 & 817.3 & 239.15 & 817.2 \\
\hline 237.15 & 818.7 & 237.15 & 818.7 & 237.15 & 818.6 \\
\hline 235.15 & 820.0 & 235.15 & 820.1 & 235.15 & 820.0 \\
\hline 233.15 & 821.4 & 233.15 & 821.5 & 233.15 & 821.4 \\
\hline
\end{tabular}




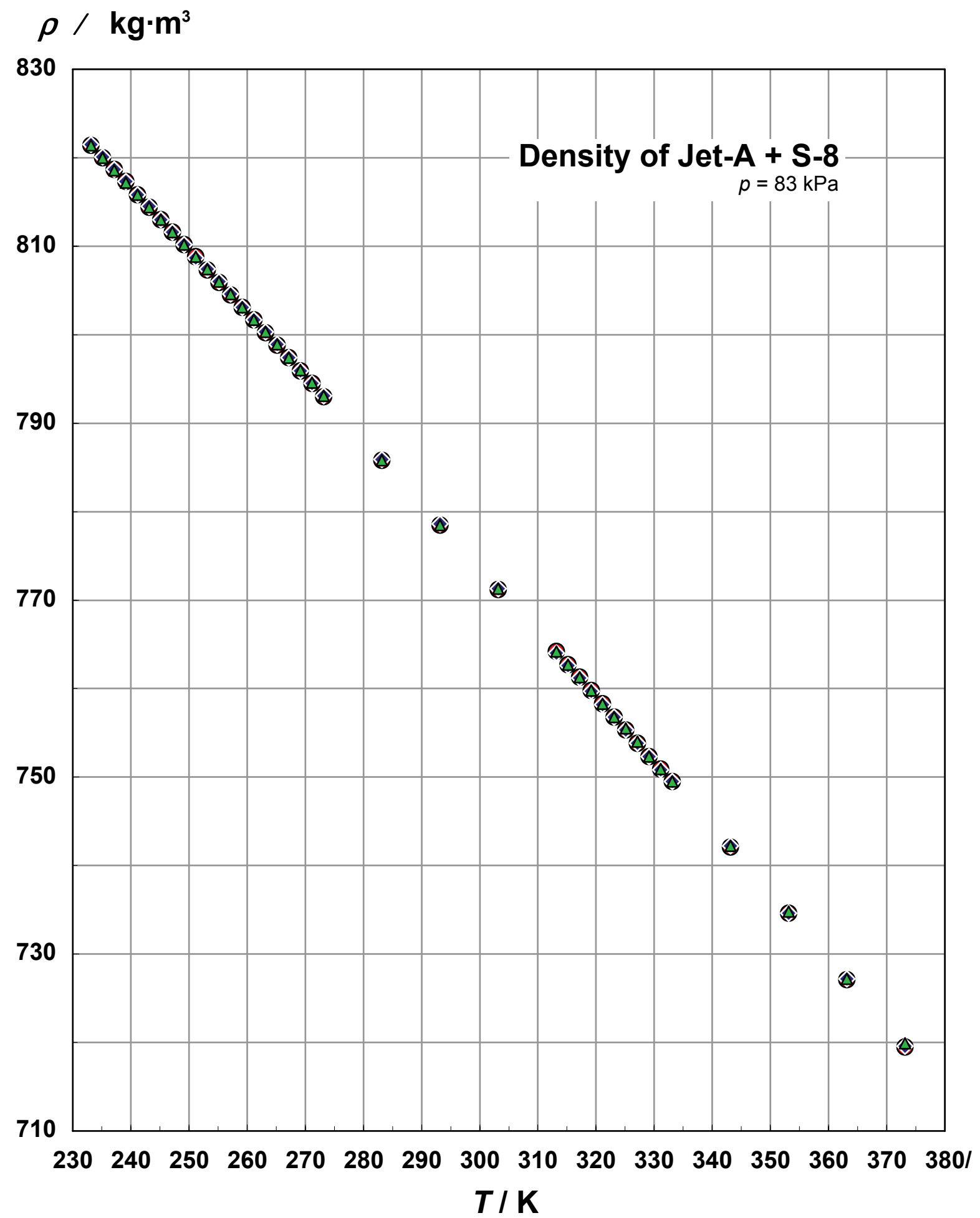

Figure 6 . The density of the $50 / 50(\mathrm{vol} / \mathrm{vol})$ mixture of Jet-A $+\mathrm{S}-8$ as a function of temperature at atmospheric (ambient) pressure. 
Table 8 . The measured viscosity of the $50 / 50(\mathrm{vol} / \mathrm{vol})$ mixture of Jet-A $+\mathrm{S}-8$ at $83.4 \mathrm{kPa}$.

\begin{tabular}{|c|c|c|c|c|c|c|c|c|}
\hline $\begin{array}{c}\text { Temp- } \\
\text { erature } \\
T \\
\end{array}$ & $\begin{array}{c}\text { Absolute } \\
\text { Viscosity } \eta\end{array}$ & $\begin{array}{c}\text { Kinem. } \\
\text { Viscosity } \\
v\end{array}$ & $\begin{array}{c}\text { Temp- } \\
\text { erature } \\
T \\
\end{array}$ & $\begin{array}{c}\text { Absolute } \\
\text { Viscosity } \\
\eta \\
\end{array}$ & $\begin{array}{c}\text { Kinem. } \\
\text { Viscosity } \\
v\end{array}$ & $\begin{array}{c}\text { Temp- } \\
\text { erature } \\
T\end{array}$ & $\begin{array}{c}\text { Absolute } \\
\text { Viscosity } \eta\end{array}$ & $\begin{array}{c}\text { Kinem. } \\
\text { Viscosity } \\
v\end{array}$ \\
\hline $\mathbf{K}$ & $\mathrm{mPa} \cdot \mathbf{s}$ & $\mathrm{mm}^{2} \cdot \mathrm{s}^{-1}$ & $\mathbf{K}$ & $\mathbf{m P a} \cdot \mathbf{s}$ & $\mathrm{mm}^{2} \cdot \mathrm{s}^{-1}$ & $\mathbf{K}$ & $\mathbf{m P a} \cdot \mathbf{s}$ & $\mathrm{mm}^{2} \cdot \mathrm{s}^{-1}$ \\
\hline \multicolumn{3}{|c|}{ Run 1} & \multicolumn{3}{|c|}{ Run 2} & \multicolumn{3}{|c|}{ Run 3} \\
\hline 373.15 & 0.5217 & 0.7251 & 373.16 & 0.5216 & 0.7247 & 373.15 & 0.5213 & 0.7241 \\
\hline 363.15 & 0.5794 & 0.7969 & 363.15 & 0.5797 & 0.7972 & 363.15 & 0.5796 & 0.7971 \\
\hline 353.15 & 0.6489 & 0.8833 & 353.15 & 0.6493 & 0.8839 & 353.15 & 0.6492 & 0.8836 \\
\hline 343.15 & 0.7297 & 0.9832 & 343.15 & 0.7304 & 0.9841 & 343.15 & 0.7302 & 0.9839 \\
\hline 333.15 & 0.8254 & 1.101 & 333.15 & 0.8263 & 1.102 & 333.15 & 0.8263 & 1.102 \\
\hline 331.15 & 0.8483 & 1.130 & 331.15 & 0.8488 & 1.130 & 331.15 & 0.8500 & 1.132 \\
\hline 329.15 & 0.8705 & 1.157 & 329.15 & 0.8710 & 1.158 & 329.15 & 0.8724 & 1.160 \\
\hline 327.15 & 0.8936 & 1.185 & 327.15 & 0.8942 & 1.186 & 327.15 & 0.8956 & 1.188 \\
\hline 325.15 & 0.9177 & 1.215 & 325.15 & 0.9184 & 1.216 & 325.15 & 0.9199 & 1.218 \\
\hline 321.15 & 0.9690 & 1.278 & 321.15 & 0.9700 & 1.279 & 321.15 & 0.9716 & 1.281 \\
\hline 319.15 & 0.9964 & 1.311 & 319.15 & 0.9975 & 1.313 & 319.15 & 0.9991 & 1.315 \\
\hline 317.15 & 1.025 & 1.347 & 317.15 & 1.026 & 1.348 & 317.15 & 1.028 & 1.350 \\
\hline 315.15 & 1.055 & 1.383 & 315.15 & 1.056 & 1.385 & 315.15 & 1.058 & 1.387 \\
\hline 303.15 & 1.272 & 1.649 & 303.15 & 1.272 & 1.650 & 303.15 & 1.273 & 1.651 \\
\hline 283.15 & 1.842 & 2.344 & 283.15 & 1.843 & 2.345 & 283.15 & 1.844 & 2.347 \\
\hline 273.15 & 2.310 & 2.912 & 273.15 & 2.309 & 2.912 & 273.15 & 2.315 & 2.918 \\
\hline 271.15 & 2.427 & 3.054 & 271.15 & 2.427 & 3.054 & 271.15 & 2.432 & 3.061 \\
\hline 269.15 & 2.554 & 3.208 & 269.15 & 2.554 & 3.208 & 269.15 & 2.560 & 3.215 \\
\hline 267.15 & 2.692 & 3.376 & 267.15 & 2.692 & 3.376 & 267.15 & 2.698 & 3.383 \\
\hline 265.15 & 2.842 & 3.558 & 265.15 & 2.843 & 3.558 & 265.15 & 2.849 & 3.567 \\
\hline 263.15 & 3.007 & 3.758 & 263.15 & 3.008 & 3.759 & 263.15 & 3.014 & 3.767 \\
\hline 261.15 & 3.187 & 3.976 & 261.15 & 3.189 & 3.978 & 261.15 & 3.195 & 3.986 \\
\hline 259.15 & 3.385 & 4.215 & 259.15 & 3.387 & 4.217 & 259.15 & 3.394 & 4.226 \\
\hline 257.15 & 3.603 & 4.479 & 257.15 & 3.605 & 4.481 & 257.15 & 3.612 & 4.490 \\
\hline 255.15 & 3.844 & 4.770 & 255.15 & 3.844 & 4.769 & 255.15 & 3.853 & 4.781 \\
\hline 253.15 & 4.110 & 5.091 & 253.15 & 4.111 & 5.091 & 253.15 & 4.121 & 5.104 \\
\hline 251.15 & 4.405 & 5.447 & 251.15 & 4.405 & 5.446 & 251.15 & 4.417 & 5.462 \\
\hline 249.15 & 4.735 & 5.844 & 249.15 & 4.735 & 5.844 & 249.15 & 4.748 & 5.860 \\
\hline 247.15 & 5.103 & 6.288 & 247.15 & 5.103 & 6.288 & 247.15 & 5.117 & 6.305 \\
\hline 245.15 & 5.516 & 6.784 & 245.15 & 5.516 & 6.784 & 245.15 & 5.531 & 6.803 \\
\hline 243.15 & 5.981 & 7.343 & 243.15 & 5.981 & 7.343 & 243.15 & 5.997 & 7.363 \\
\hline 241.15 & 6.435 & 7.888 & 241.15 & 6.436 & 7.888 & 241.15 & 6.453 & 7.910 \\
\hline 239.15 & 7.030 & 8.601 & 239.15 & 7.030 & 8.602 & 239.15 & 7.049 & 8.625 \\
\hline 237.15 & 7.706 & 9.413 & 237.15 & 7.706 & 9.413 & 237.15 & 7.727 & 9.438 \\
\hline 235.15 & 8.478 & 10.34 & 235.15 & 8.478 & 10.34 & 235.15 & 8.500 & 10.37 \\
\hline 233.15 & 9.363 & 11.40 & 233.15 & 9.363 & 11.40 & 233.15 & 9.388 & 11.43 \\
\hline
\end{tabular}




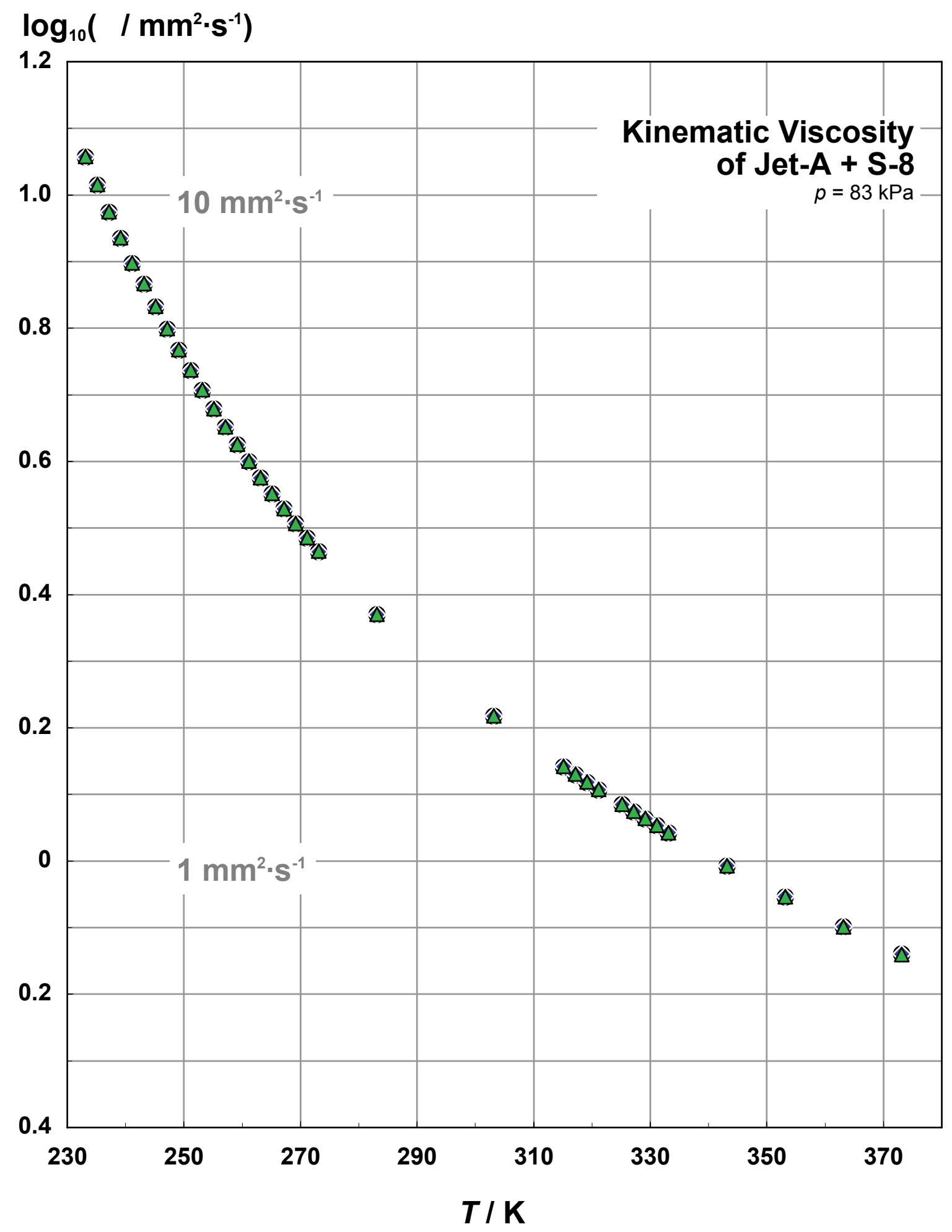

Figure 8. A plot of the kinematic viscosity of the 50/50 mixture of Jet-A + S-8. 
$\log _{10}(/ \mathrm{mPa} \cdot \mathrm{s})$

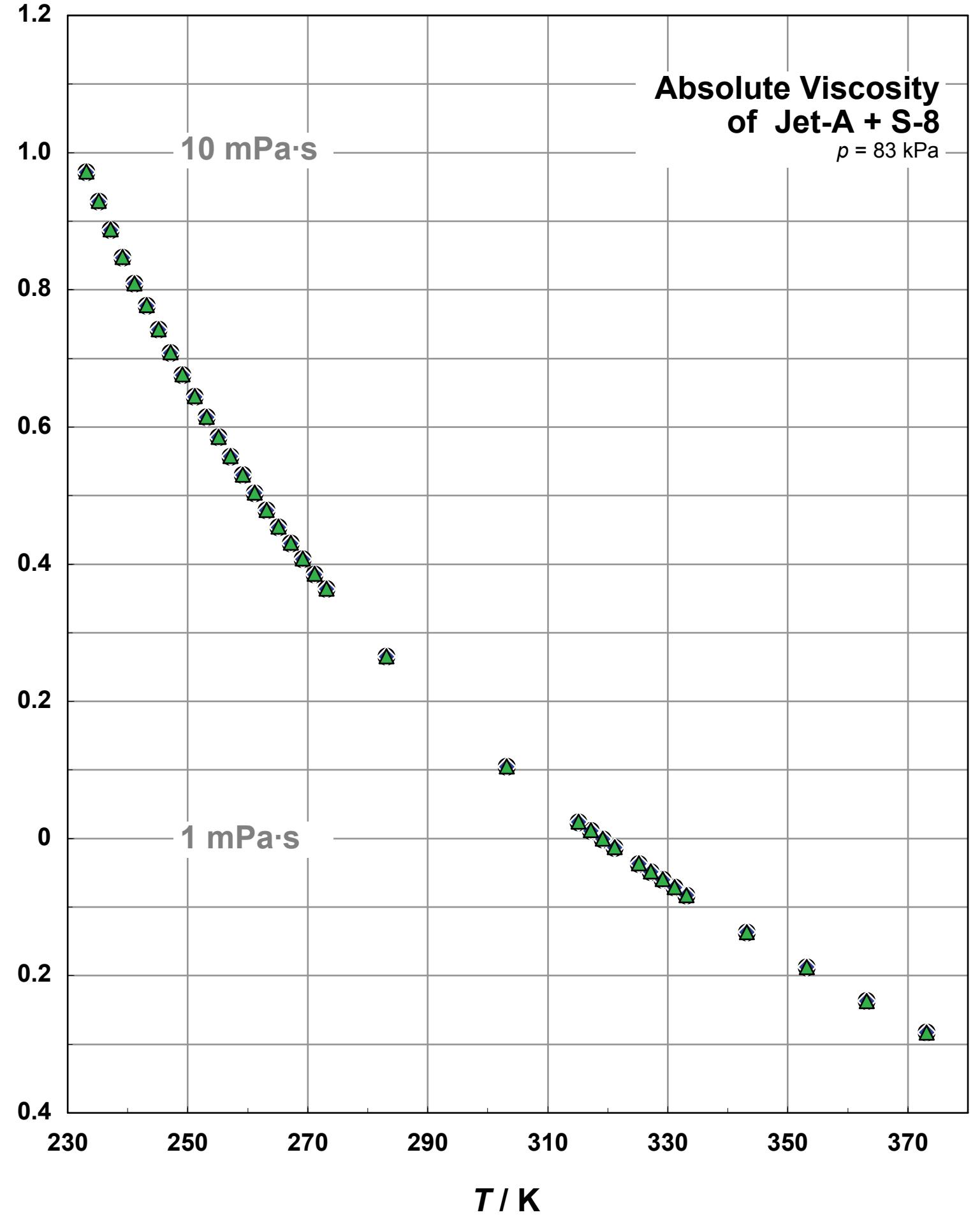

Figure 9. A plot of the absolute viscosity of the 50/50 mixture of Jet-A + S-8. 


\section{Speed of Sound Measurements (at Atmospheric Pressure) for 50/50 Jet-A + S-8}

The speed of sound in liquid samples of S-8 was measured with a sound speed analyzer DSA 5000 that is similar to the SVM 3000 viscodensimeter in design and appearance. It also includes a vibrating U-tube densimeter and a pulse-echo speed of sound measurement cell that is illustrated below. However, the temperature range is limited from $0{ }^{\circ} \mathrm{C}$ to $70{ }^{\circ} \mathrm{C}$. The measurement uncertainty is stated for both properties as $0.01 \%$ to $0.1 \%$, with repeatabilities of $0.001 \mathrm{~kg} \cdot \mathrm{m}^{-3}$ in the density and $0.1 \mathrm{~m} \cdot \mathrm{s}^{-1}$ in the speed of sound measurement. The density measurement in the DSA 5000 is more accurate than that in the viscodensimeter. By design, the densimeter in the viscodensimeter was made only as accurate as necessary in view of the higher uncertainty of the viscosity measurement. This device is shown schematically in Figure 10. The measured values for the speed of sound in the mixture of Jet-A + S- 8 are provided in Table 9, and a plot of these values against temperature is provided in Figure 11. Adiabatic compressibilities were obtained from the measured densities and speeds of sound via the thermodynamic relation $\kappa_{s}=-(\partial V / \partial p)_{s} / V=1 /\left(\rho w^{2}\right)$, where $V$ denotes volume, $p$ is pressure, and $w$ the speed of sound. Subscript $s$ indicates "at constant entropy $s$." The calculated values are also reported in Table 9 and they are plotted in Figure 12.

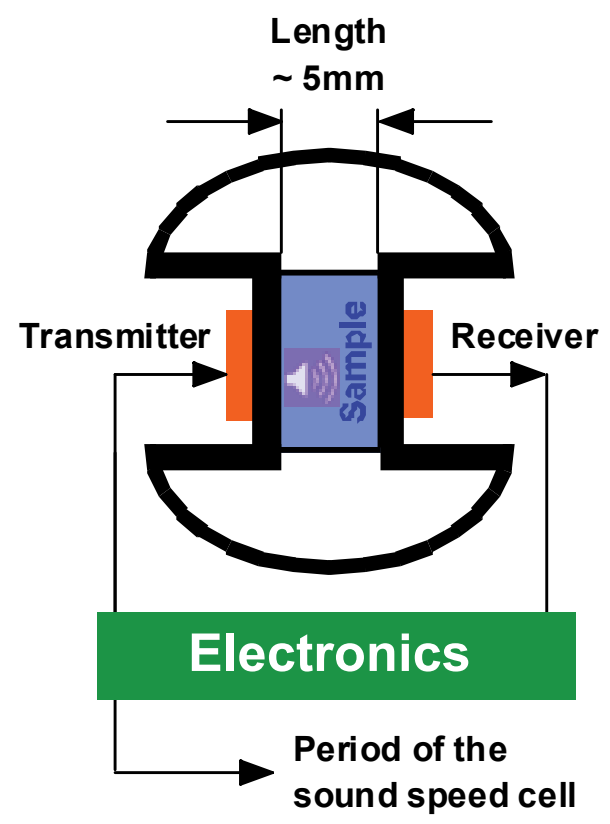

Figure 10. Schematic of the sound speed measurement in the DSA 5000. 
Table 9. Speeds of sound and adiabatic compressibilities of Jet-A + S8 mixture measured in the Sound Speed Analyzer DSA 5000. The ambient pressure during the measurements was $83 \mathrm{kPa}$.

\begin{tabular}{|c|c|c|c|c|c|c|c|c|}
\hline $\begin{array}{c}\text { Temp- } \\
\text { erature } \\
T\end{array}$ & $\begin{array}{l}\text { Speed of } \\
\text { sound } \\
w\end{array}$ & $\begin{array}{c}\text { Adiab. } \\
\text { compres- } \\
\text { sibility } \boldsymbol{\kappa}_{\boldsymbol{s}}\end{array}$ & $\begin{array}{c}\text { Temp- } \\
\text { erature } \\
T\end{array}$ & $\begin{array}{c}\text { Speed of } \\
\text { sound } \\
w\end{array}$ & $\begin{array}{c}\text { Adiab. } \\
\text { compres- } \\
\text { sibility } \boldsymbol{\kappa}_{\text {s }}\end{array}$ & $\begin{array}{c}\text { Temp- } \\
\text { erature } \\
T\end{array}$ & $\begin{array}{c}\text { Speed of } \\
\text { sound } \\
w\end{array}$ & $\begin{array}{c}\text { Adiab. } \\
\text { compres- } \\
\text { sibility } \boldsymbol{\kappa}_{\boldsymbol{S}}\end{array}$ \\
\hline $\mathbf{K}$ & $m \cdot \mathbf{s}^{-1}$ & $\mathrm{TPa}^{-1}$ & $\mathbf{K}$ & $\mathbf{m} \cdot \mathbf{s}^{-1}$ & $\mathrm{TPa}^{-1}$ & $\mathbf{K}$ & $\mathbf{m} \cdot \mathbf{s}^{-1}$ & $\mathrm{TPa}^{-1}$ \\
\hline \multicolumn{3}{|c|}{ Run 1} & \multicolumn{3}{|c|}{ Run 2} & \multicolumn{3}{|c|}{ Run 3} \\
\hline 343.15 & 1113.14 & 1090.16 & 343.15 & 1111.09 & 1094.00 & 343.15 & 1109.43 & 1097.51 \\
\hline 333.15 & 1149.68 & 1011.70 & 333.15 & 1147.65 & 1015.14 & 333.15 & 1145.94 & 1018.36 \\
\hline 323.15 & 1186.39 & 940.620 & 323.15 & 1184.76 & 943.116 & 323.15 & 1183.18 & 945.796 \\
\hline 313.15 & 1223.58 & 875.581 & 313.15 & 1222.25 & 877.310 & 313.15 & 1220.87 & 879.508 \\
\hline 303.15 & 1261.50 & 815.544 & 303.15 & 1260.38 & 816.698 & 303.15 & 1259.13 & 818.562 \\
\hline 293.15 & 1299.99 & 760.250 & 293.15 & 1299.10 & 760.929 & 293.15 & 1298.02 & 762.394 \\
\hline 283.15 & 1338.99 & 709.230 & 283.15 & 1338.40 & 709.468 & 283.15 & 1337.51 & 710.520 \\
\hline 278.15 & 1358.70 & 685.285 & 278.15 & 1358.00 & 685.069 & 278.15 & 1356.78 & 685.217 \\
\hline
\end{tabular}




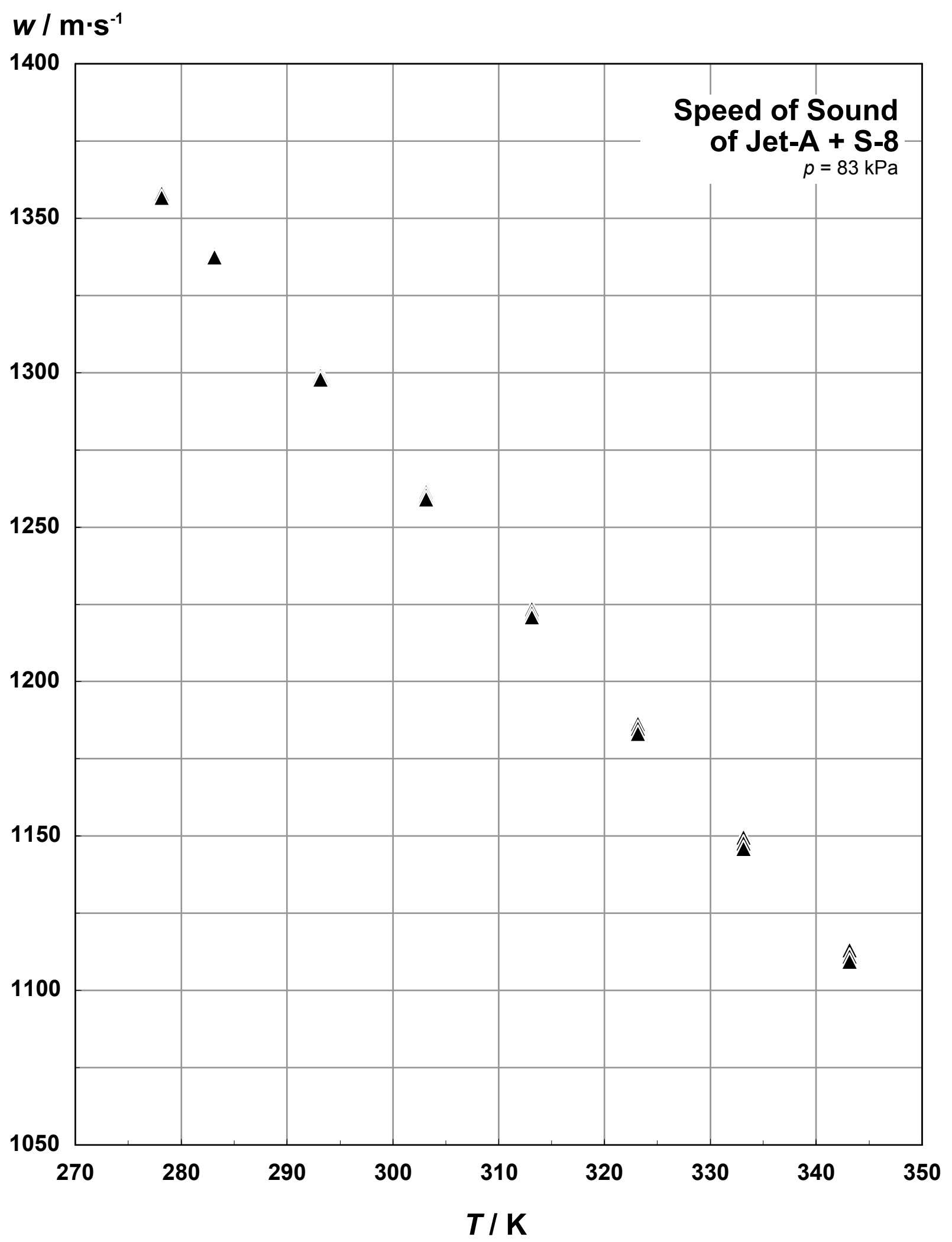

Figure 11. A plot of the speed of sound in a 50/50 mixture of Jet-A + S-8. 


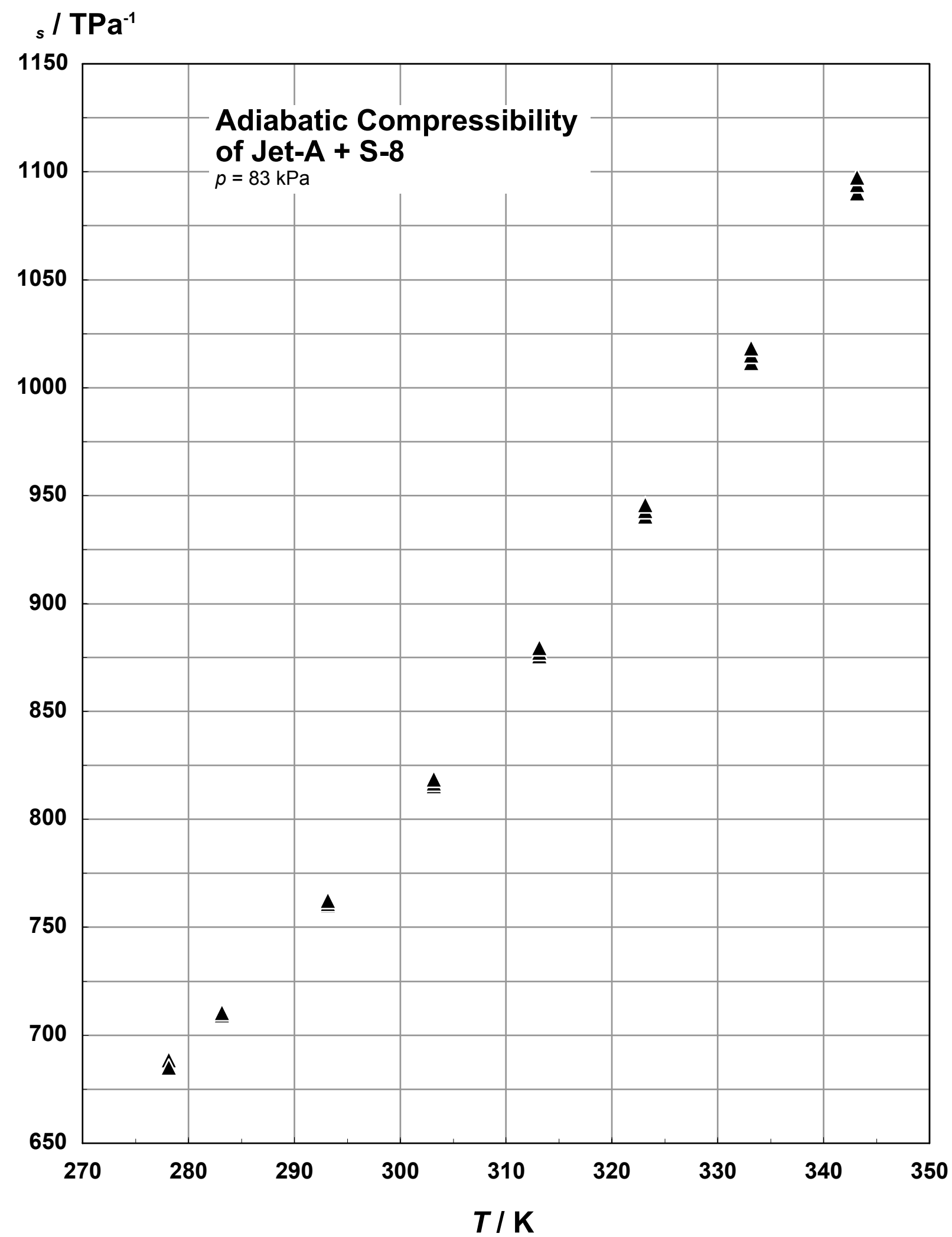

Figure 12: A plot of the adiabatic compressibility of a 50/50 mixture of Jet-A $+\mathrm{S}-8$. 


\section{Correlations for the Density, Viscosity, and Speed of Sound of 50/50 Jet-A + S-8}

The previously reported experimental results for the density, viscosity, and speed of sound of $50 / 50$ Jet- $\mathrm{A}+\mathrm{S}-8$ at ambient pressure were correlated to facilitate their practical application. The temperature dependence of the density and of the speed of sound is each represented by a quadratic polynomial

$$
\begin{aligned}
& \rho=a_{0}+a_{1} T+a_{2} T^{2}, \text { and } \\
& w=c_{0}+c_{1} T+c_{2} T^{2},
\end{aligned}
$$

while the temperature dependence of the absolute viscosity requires the more complex formulation

$$
\frac{\eta}{\eta_{0}}=\exp \left(\beta_{1}+\frac{\beta_{2}}{T_{r}}+\beta_{3} \ln \left(T_{r}\right)+\beta_{4} T_{r}^{\beta_{5}}\right) .
$$

The adjustable parameters in eqs. (1) and (2) were determined by linear and those in eq. (3) by nonlinear least squares regression. The optimal values are listed in Table 10 with their standard deviations and the applicable temperature ranges.

\begin{tabular}{|c|c|c|c|c|c|c|}
\hline & Density, e & (1) & Viscosity & (3) & Speed of sou & eq. (2) \\
\hline & $233 \mathrm{~K} \leq T \leq$ & $373 \mathrm{~K}$ & $233 \mathrm{~K} \leq 7$ & $73 \mathrm{~K}$ & $278 \mathrm{~K} \leq T$ & $43 \mathrm{~K}$ \\
\hline$i$ & $\begin{array}{c}\text { Parameter } \\
\text { value } \\
a_{i}\end{array}$ & $\begin{array}{c}\text { Stand. } \\
\text { Dev. } \\
s_{i}\end{array}$ & $\begin{array}{c}\text { Parameter } \\
\text { value } \\
\beta_{i}\end{array}$ & $\begin{array}{c}\text { Stand. } \\
\text { Dev. } \\
s_{i}\end{array}$ & $\begin{array}{c}\text { Parameter } \\
\text { value } \\
c_{i}\end{array}$ & $\begin{array}{c}\text { Stand. } \\
\text { Dev. } \\
s_{i}\end{array}$ \\
\hline 0 & 976.37964 & 0.44 & & & 2659.2926 & 56 \\
\hline 1 & -0.62516115 & $3.0 \cdot 10^{-3}$ & 8.0698334 & 0.58 & -5.3967658 & 0.37 \\
\hline 2 & $-1.6811101 \cdot 10^{-4}$ & $5.2 \mathrm{E} \cdot 10^{-6}$ & -8.9055146 & 0.68 & $2.5802235 \cdot 10^{-3}$ & $5.9 \cdot 10^{-4}$ \\
\hline 3 & & & -8.4990463 & 0.39 & & \\
\hline 4 & & & 1.6747087 & 0.10 & & \\
\hline 5 & & & -4.2001948 & 0.075 & & \\
\hline & Max. dev. & $0.029 \%$ & & $0.69 \%$ & & $0.073 \%$ \\
\hline & Min. dev. & $-0.028 \%$ & & $-0.61 \%$ & & $-0.046 \%$ \\
\hline & Avg. abs. dev. & $0.0076 \%$ & & $0.20 \%$ & & $0.026 \%$ \\
\hline & Std. dev. & $0.0098 \%$ & & $0.26 \%$ & & $0.031 \%$ \\
\hline
\end{tabular}

Table 10: Parameter values and associated standard deviations of the correlations eqs. (1-3) for a 50/50 mixture of Jet-A + S-8. 


\section{Compressed Liquid Density Measurements for 50/50 Jet-A + S-8}

A schematic of the apparatus used to measure compressed liquid densities over the temperature range of $270 \mathrm{~K}$ to $470 \mathrm{~K}$ and to pressures of $50 \mathrm{MPa}$ is illustrated in Figure 13. The heart of the apparatus is a commercial vibrating tube densimeter; however, several physical and procedural improvements have been implemented beyond that of the commercial instrument operated in a stand-alone mode. The densimeter is housed in a specially designed two-stage thermostat for improved temperature control. The uncertainty in the temperature is $0.02 \mathrm{~K}$, with short-term stability of $0.005 \mathrm{~K}$. Pressures are measured with an oscillating quartz crystal pressure transducer with an uncertainty of $10 \mathrm{kPa}$. The densimeter was calibrated with measurements of vacuum, propane and toluene, over the temperature and pressure range of the apparatus to achieve an uncertainty in density of $1 \mathrm{~kg} / \mathrm{m}^{3}$.

The apparatus was designed, and software was written so that the operation and data acquisition are fully automated. Data are taken along isotherms over a temperature/ pressure matrix programmed by the operator prior to the start of measurements. The electronically actuated pneumatic valves and programmable syringe pump are used to move from one pressure to the next and/or flush fresh sample through the system. Operation of the densimeter in this manner allows for measurements to be made $24 \mathrm{~h}$ per day. The densimeter described above has been used to measure 121 compressed liquid densities of a 50/50 (vol/vol) Jet-A + S-8 sample from $270 \mathrm{~K}$ to $470 \mathrm{~K}$ at pressures from $0.5 \mathrm{MPa}$ to $30 \mathrm{MPa}$. The data are listed in Table 11.

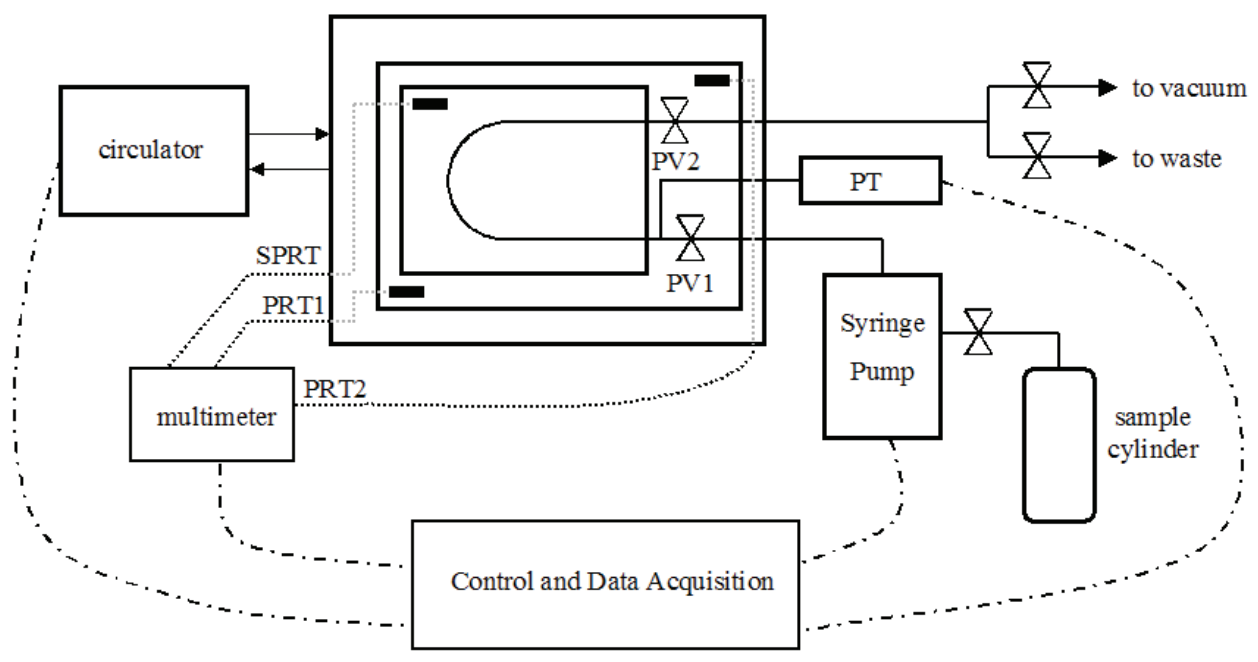

Figure 13. Schematic of the compressed liquid density apparatus. 


\section{$\mathrm{kg} \cdot \mathrm{m}^{3}$}

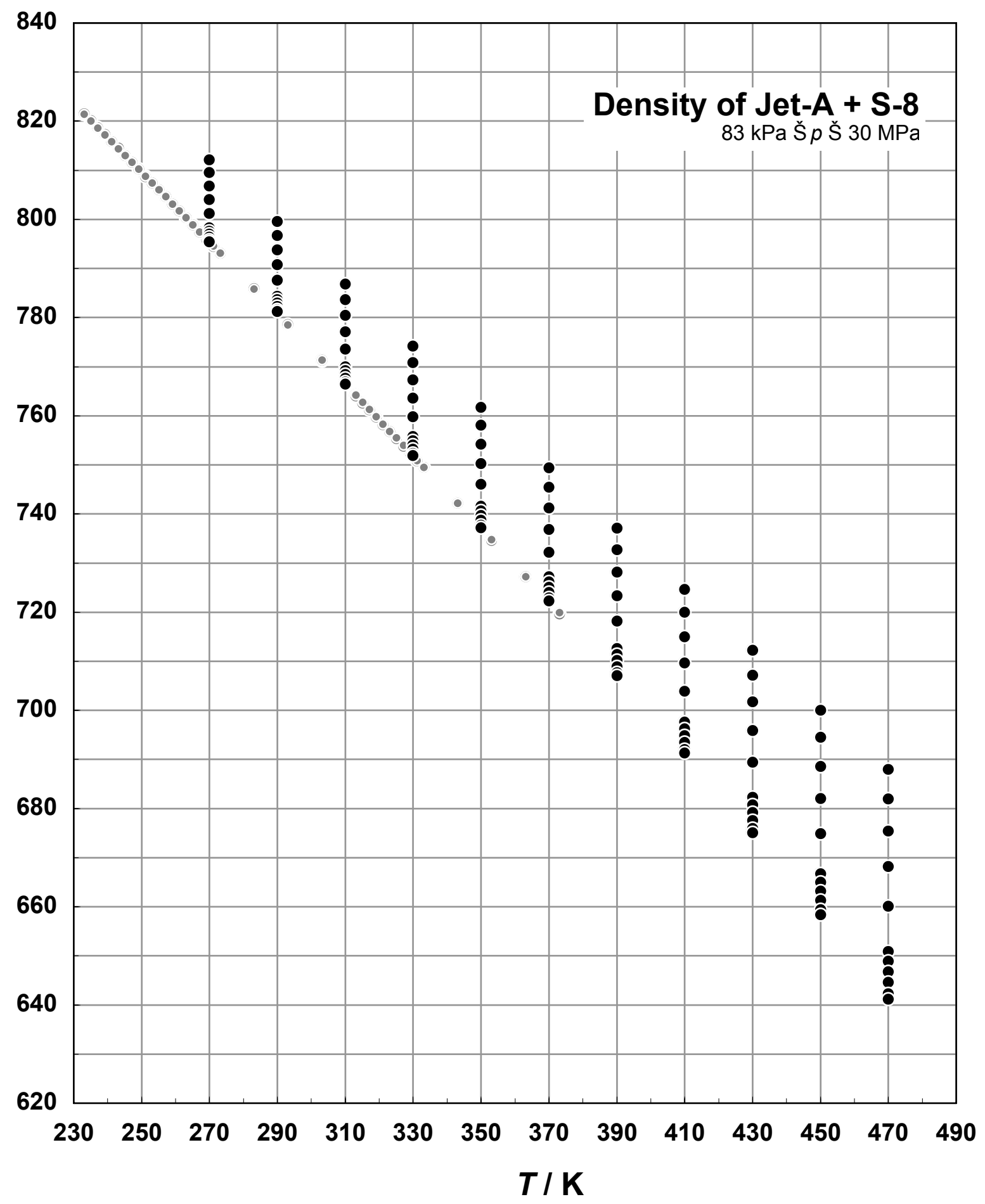

Figure 14. Compressed liquid densities of Jet-A + S-8 50/50 (vol/vol) mixture as a function of temperature. The measurement results at ambient pressure are indicated by light grey symbols. 
Table 11. Compressed liquid density measurements on 50/50 Jet-A $+\mathrm{S}-8$.

\begin{tabular}{|c|c|c|c|c|c|}
\hline $\begin{array}{c}\text { Temperature } \\
{[\mathrm{K}]}\end{array}$ & $\begin{array}{c}\text { Pressure } \\
{[\mathrm{MPa}]}\end{array}$ & $\begin{array}{l}\text { Density } \\
{[\mathrm{kg} / \mathrm{m} 3]}\end{array}$ & $\begin{array}{c}\text { Temperature } \\
{[\mathrm{K}]}\end{array}$ & $\begin{array}{c}\text { Pressure } \\
{[\mathrm{MPa}]}\end{array}$ & $\begin{array}{l}\text { Density } \\
{[\mathrm{kg} / \mathrm{m} 3]}\end{array}$ \\
\hline 270.00 & 30.018 & 812.15 & 370.00 & 4.007 & 726.14 \\
\hline 270.00 & 25.007 & 809.52 & 370.00 & 3.006 & 725.07 \\
\hline 270.00 & 20.017 & 806.83 & 370.00 & 2.011 & 723.99 \\
\hline 270.00 & 15.011 & 804.05 & 370.00 & 1.001 & 722.88 \\
\hline 270.00 & 10.013 & 801.19 & 370.00 & 0.508 & 722.33 \\
\hline 270.00 & 5.011 & 798.23 & 390.00 & 30.016 & 737.06 \\
\hline 270.00 & 4.001 & 797.61 & 390.00 & 25.013 & 732.73 \\
\hline 270.00 & 3.006 & 797.01 & 390.00 & 20.013 & 728.18 \\
\hline 270.00 & 2.006 & 796.39 & 390.00 & 15.005 & 723.33 \\
\hline 270.00 & 1.010 & 795.77 & 390.00 & 10.016 & 718.16 \\
\hline 270.00 & 0.515 & 795.45 & 390.00 & 5.013 & 712.56 \\
\hline 290.00 & 30.014 & 799.58 & 390.00 & 4.004 & 711.36 \\
\hline 290.00 & 25.004 & 796.73 & 390.00 & 2.998 & 710.14 \\
\hline 290.00 & 20.010 & 793.80 & 390.00 & 2.002 & 708.92 \\
\hline 290.00 & 15.002 & 790.76 & 390.00 & 1.006 & 707.68 \\
\hline 290.00 & 10.006 & 787.62 & 390.00 & 0.509 & 707.05 \\
\hline 290.00 & 5.014 & 784.35 & 410.00 & 30.011 & 724.65 \\
\hline 290.00 & 4.009 & 783.67 & 410.00 & 25.011 & 719.97 \\
\hline 290.00 & 3.010 & 782.98 & 410.00 & 20.000 & 714.98 \\
\hline 290.00 & 2.008 & 782.28 & 410.00 & 15.000 & 709.65 \\
\hline 290.00 & 1.010 & 781.58 & 410.00 & 10.007 & 703.88 \\
\hline 290.00 & 0.505 & 781.21 & 410.00 & 5.006 & 697.59 \\
\hline 310.00 & 30.004 & 786.80 & 410.00 & 4.009 & 696.25 \\
\hline 310.00 & 25.010 & 783.68 & 410.00 & 3.005 & 694.88 \\
\hline 310.00 & 20.010 & 780.45 & 410.00 & 2.005 & 693.47 \\
\hline 310.00 & 15.010 & 777.09 & 410.00 & 1.008 & 692.05 \\
\hline 310.00 & 10.004 & 773.59 & 410.00 & 0.509 & 691.32 \\
\hline 310.00 & 5.006 & 769.95 & 430.00 & 30.005 & 712.26 \\
\hline 310.00 & 4.007 & 769.18 & 430.00 & 25.007 & 707.16 \\
\hline 310.00 & 3.017 & 768.42 & 430.00 & 20.011 & 701.72 \\
\hline 310.00 & 2.006 & 767.60 & 430.00 & 15.011 & 695.85 \\
\hline 310.00 & 1.008 & 766.83 & 430.00 & 10.011 & 689.41 \\
\hline 310.00 & 0.503 & 766.42 & 430.00 & 5.014 & 682.31 \\
\hline 330.00 & 30.001 & 774.17 & 430.00 & 4.000 & 680.76 \\
\hline 330.00 & 25.004 & 770.79 & 430.00 & 3.010 & 679.21 \\
\hline 330.00 & 19.995 & 767.27 & 430.00 & 2.005 & 677.60 \\
\hline 330.00 & 15.003 & 763.61 & 430.00 & 1.006 & 675.95 \\
\hline 330.00 & 10.012 & 759.79 & 430.00 & 0.509 & 675.10 \\
\hline 330.00 & 5.002 & 755.76 & 450.00 & 29.993 & 700.02 \\
\hline 330.00 & 4.008 & 754.91 & 450.00 & 25.003 & 694.51 \\
\hline 330.00 & 3.012 & 754.07 & 450.00 & 20.012 & 688.55 \\
\hline 330.00 & 2.007 & 753.21 & 450.00 & 15.014 & 682.04 \\
\hline 330.00 & 1.006 & 752.34 & 450.00 & 10.010 & 674.85 \\
\hline 330.00 & 0.513 & 751.91 & 450.00 & 5.005 & 666.76 \\
\hline
\end{tabular}




\begin{tabular}{|c|c|c|c|c|c|}
\hline $\begin{array}{c}\text { Temperature } \\
{[\mathrm{K}]}\end{array}$ & $\begin{array}{c}\text { Pressure } \\
{[\mathrm{MPa}]}\end{array}$ & $\begin{array}{c}\text { Density } \\
{[\mathrm{kg} / \mathrm{m} 3]}\end{array}$ & $\begin{array}{c}\text { Temperature } \\
{[\mathrm{K}]}\end{array}$ & $\begin{array}{c}\text { Pressure } \\
{[\mathrm{MPa}]}\end{array}$ & $\begin{array}{c}\text { Density } \\
{[\mathrm{kg} / \mathrm{m} 3]}\end{array}$ \\
\hline 350.00 & 30.002 & 761.73 & 450.00 & 4.006 & 665.01 \\
\hline 350.00 & 25.007 & 758.07 & 450.00 & 3.012 & 663.21 \\
\hline 350.00 & 20.006 & 754.24 & 450.00 & 2.001 & 661.33 \\
\hline 350.00 & 15.009 & 750.23 & 450.00 & 1.009 & 659.42 \\
\hline 350.00 & 10.017 & 746.02 & 450.00 & 0.501 & 658.41 \\
\hline 350.00 & 5.006 & 741.53 & 470.00 & 30.021 & 687.99 \\
\hline 350.00 & 4.015 & 740.60 & 470.00 & 25.004 & 681.96 \\
\hline 350.00 & 3.001 & 739.64 & 470.00 & 20.003 & 675.41 \\
\hline 350.00 & 2.006 & 738.69 & 470.00 & 14.995 & 668.18 \\
\hline 350.00 & 1.012 & 737.71 & 470.00 & 10.011 & 660.13 \\
\hline 350.00 & 0.508 & 737.21 & 470.00 & 5.013 & 650.91 \\
\hline 370.00 & 30.007 & 749.41 & 470.00 & 4.005 & 648.87 \\
\hline 370.00 & 25.009 & 745.44 & 470.00 & 3.007 & 646.76 \\
\hline 370.00 & 20.006 & 741.26 & 470.00 & 2.003 & 644.58 \\
\hline 370.00 & 15.011 & 736.85 & 470.00 & 1.006 & 642.31 \\
\hline 370.00 & 10.006 & 732.18 & 470.00 & 0.516 & 641.16 \\
\hline 370.00 & 5.004 & 727.18 & & & \\
\hline
\end{tabular}

\section{References}

[1] Handbook of aviation fuel properties, CRC Report No. 635, Alpharetta, GA: Coordinating Research Council (CRC) (2004).

[2] MSDS, S-8 Synthetic Jet Fuel, material safety data sheet. Syntroleum Corp., Tulsa, OK (2005).

[3] T. J. Bruno, P. D. N. Svoronos, CRC handbook of basic tables for chemical analysis, 2nd ed., Boca Raton: CRC Press (2004).

[4] T. J. Bruno, P. D. N. Svoronos, CRC handbook of fundamental spectroscopic correlation charts. Boca Raton: Taylor and Francis CRC Press (2005).

[5] Standard test method for boiling range distribution of petroleum fractions by gas chromatography, ASTM Standard D2789-02, ASTM Annual Book of Standards (2004).

[6] Standard test method for distillation of petroleum products at atmospheric pressure, ASTM Standard D 86-04b, Book of Standards Volume 05.01. American Society for Testing and Materials: West Conshohocken, PA (2004).

[7] T. J. Bruno, Method and apparatus for precision in-line sampling of distillate. Sep. Sci. Technol. 41(2): 309-314 (2006).

[8] T. J. Bruno, Improvements in the measurement of distillation curves - part 1: a composition-explicit approach. Ind. Eng. Chem. Res. 45: 4371-4380 (2006).

[9] T. J. Bruno, B. L. Smith, Improvements in the measurement of distillation curves - Part 2: Application to aerospace/aviation fuels RP-1 and S-8. Ind. Eng. Chem. Res. 45: 43814388, (2006). 
[10] T. J. Bruno, B. L. Smith, Enthalpy of combustion of fuels as a function of distillate cut: application of an advanced distillation curve method. Energy and Fuels 20: 2109-2116 (2006).

[11] B. L. Smith, T. J. Bruno, Advanced distillation curve measurement with a model predictive temperature controller. Int. J. Thermophys., 2006. 27: p. 1419-1434.

[12] B. L. Smith, T. J. Bruno, Improvements in the measurement of distillation curves-Part 3: Application to gasoline and gasoline + methanol mixtures. Ind. Eng. Chem. Res. 46: 297-309 (2006).

[13] B. L. Smith, T. J. Bruno, Improvements in the measurement of distillation curves-Part 4: application to the aviation turbine fuel Jet-A. Ind. Eng. Chem. Res. 46: 310-320 (2006).

[14] B. L. Smith, T. J. Bruno, Application of a composition-explicit distillation curve metrology to mixtures of Jet-A + synthetic Fischer-Tropsch S-8. J. Propul. Power. (submitted).

[15] S. Young, Correction of boiling points of liquids from observed to normal pressures. Proc. Chem. Soc. 81: 777 (1902).

[16] S. Young, Fractional distillation. London: Macmillan and Co., Ltd. (1903).

[17] S. Young, Distillation principles and processes. London: Macmillan and Co., Ltd. (1922).

[18] T. J. Bruno, The properties of S-8. Final Report for MIPR F4FBEY6237G001, Air Force Research Laboratory (2006).

[19] T. J. Bruno, M. L. Huber, A. Laesecke, E. W. Lemmon, R. A. Perkins, Thermochemical and thermophysical properties of JP-10. Natl. Inst. Stand. Technol. NISTIR 6640 (2006). 